\title{
Synthesis and property of polyurethane elastomer for biomedical applications based on nonaromatic isocyanates, polyesters, and ethylene glycol
}

\author{
Piotr Król ${ }^{1} \cdot$ Łukasz Uram ${ }^{1}$ • Bożena Król ${ }^{1} \cdot$ Kinga Pielichowska $^{2} \cdot$ Marta Sochacka-Piętal $^{1} \cdot$ Małgorzata Walczak $^{1}$
}

Received: 30 January 2020 / Revised: 15 April 2020 / Accepted: 24 April 2020 / Published online: 28 May 2020

(C) The Author(s) 2020

\begin{abstract}
Polyurethane (PU) elastomers were synthesized by the reaction of HDI or IPDI diisocyanates and poly( $\varepsilon$-caprolactone) (PCL or poly(ethylene adipate) (PA) diols and ethylene glycol as a polymer chain extender. IR, ${ }^{1} \mathrm{H}$, and ${ }^{13} \mathrm{C}$ NMR spectroscopy and X-ray analysis were used for the structural analysis of the formed films. The molecular weight distribution was examined by GPC chromatography. Based on the measured contact angles, free surface energy parameters were calculated. The obtained results were analyzed for the possible use of these polyurethanes as biomaterials. The most promising in this respect was PU-3, which was synthesized from IPDI and PCL. This was due to its high molecular weight of approximately 90,000, the presence of a crystalline phase, and the relatively high hydrophobicity, with a SEP value below $25 \mathrm{~mJ} / \mathrm{m}^{2}$. These films showed a good resistance to hydrolysis during incubation in Baxter physiological saline during 6 weeks. Both Gram-positive (Bacillus sp.) and Gram-negative (Pseudomonas sp.) types of bacterial strains were used to test the biodegradation property. Synthesized PUs are biodegradable and showed moderate or even mild cytotoxicity against human normal fibroblasts (BJ) and immortalized keratinocytes $(\mathrm{HaCaT})$, estimated with direct contact assay. The most biocompatible was PU-3 film, which revealed rather mild reactivity against both cell lines, and the least was PU-2 film, synthesized from HDI and PA (severe toxicity for HaCaTs).
\end{abstract}

Keywords Synthesis and structure of polyurethane films $\cdot$ Mechanical and surface properties $\cdot$ Microbial biodegradation $\cdot$ Contact assays with dermal fibroblasts and keratinocytes

\section{Introduction}

Polyurethanes (PU) are traditionally used as foams, elastomers, coatings, adhesives, and varnishes in some technical applications, but in recent years, they have also been used

Preliminary results were presented during the 7th International Seminar on Modern Polymeric Materials for Environmental Applications, May 15-17, 2019, in Krakow, MPM 2019 conference proceedings: P. Król, B. Król, Ł. Uram, K. Pielichowska, M. Sochacka-Piętal, M. Walczak, The study of biological properties of polyurethane elastomers for medical applications, p. 203-213.

Piotr Król

pkrol@prz.edu.pl

1 Faculty of Chemistry, Rzeszow University of Technology, Al. Powstańców Warszawy 6, 35-959 Rzeszów, Poland

2 Department of Biomaterials and Composites, Faculty of Materials Science and Ceramics, AGH University of Science and Technology, Al. Mickiewicza 30, 30-059 Krakow, Poland as biomaterials especially for the regeneration of rigid and soft tissues [1, 2]. PU-based scaffolds have been considered as a promising strategy for tissue regeneration. It is to note the synthesis by electrospinning of polyurethane fiber modified by carbon nanotubes and oxygen plasma treatment to improve its physicochemical and in vitro properties as a material useful for efficient bone reconstruction [3]. Because of polyurethane elastomers' good mechanical and surface properties, hydrolytic resistance in the presence of enzymes and bacteria, low cytotoxicity, and good hemocompatibility, they are specially produced for medical purposes. The physicochemical and biological properties of polyurethanes largely depend on the reagents used, the synthesis method, and their phase structure. Polyurethane biocompatibility means that both the materials themselves and their breakdown products in the human body are not toxic. They do not cause immunological reactions or changes in the composition of body fluids and do not show carcinogenic or mutagenic properties [4]. Polyurethanes based on 1,6-hexamethylene diisocyanate 
(HDI) or isophorone diisocyanate (IPDI) have been investigated for use as biomedical materials, since these diisocyanates are considered to be nontoxic and biosafe. For PU-based aromatic diisocyanates, the products of hydrolytic degradation are toxic aromatic amines. However, polyurethanes derived from 4,4'-diphenylmethane diisocyanate (MDI) are still preferred in biomedical applications where a material with high mechanical strength and considerable flexibility is needed $[5,6]$. In turn, polyurethanes synthesized from toluene diisocyanate (TDI) are not used as biomaterials [7]. Basically, it has been reported in the literature that PU made from aliphatic diisocyanates degrades to less nontoxic products. For this reason, research on the use of L-lysine diisocyanate (LDI) has been conducted [8]. A series of light-crosslinking waterborne polyurethanes (WBPUs) were prepared using LDI, 1,3propanediol, and L-lysine as hard segments and poly $(\varepsilon-$ caprolactone) (PCL) and poly(ethylene glycol) (PEG) as soft segments. The obtained WBPUs exhibited appropriate stretchability with a break elongation of 1400-2500\% and an excellent strength of 12-18 MPa, which could admirably meet the requirements for soft tissue engineering scaffolds. In addition, the hydrophilic surfaces of LWPUs could effectively reduce protein adsorption and platelet adhesion and favor cell proliferation compared with traditional biomedical polyurethanes [9]. It is also possible to change the PU properties by interfering with the construction of flexible segments, e.g., by introducing more flexible polysiloxane segments. Results indicated that incorporation of poly(lactic acid)-grafted hydroxyethylcellulose into PDMS-based polyurethanes leads to improvement in antibacterial activity, anti-biofilm inhibition, biocompatibility, and nonmutagenicity [10]. So modified PUs can be also valuable and used as prospective materials in the biomedical field, e.g., as thin protective layers [11-13]. However, they need to fulfill additional requirements concerning hydrolytic resistance, antibacterial properties, and above all, no cytotoxicity. In line with this trend, our previous work describes the cytotoxicity studies of polyurethane films using a direct contact toxicity test [6]. Among all PU films examined on $\mathrm{BJ}$ and $\mathrm{HaCaT}$ cell lines, samples of PU-1 and PU-3 synthesized from poly( $\varepsilon$ caprolactone) diol (PCL) had lower toxicity than the PU2 sample prepared only from poly(oxytetramethylene) diol (PTMO) [14]. All the PUs were synthesized using cycloaliphatic 4,4'-methylenebiscyclohexyl isocyanate $\left(\mathrm{H}_{12} \mathrm{MDI}\right)$ and 1,4-butanediol (BD) as a chain extender. PCL was used as a polyol for PU-1 film preparation, PTMO for the PU-2 sample, and an equimolar mixture of PCL and PTMO for the PU-3 sample. The obtained results show that hydrophobic PU films obtained from PTMO and $\mathrm{BD}$ containing polyurethane chain hydrophobic groups $-\left(\mathrm{CH}_{2}\right)_{5}-$ were more cytotoxic compared to PU films obtained from PCL as a polyol [14]. Moreover, PCL is a biodegradable and biocompatible polyol, although its degradation time is very long (over 2 years), and it possesses interesting elastic properties [6, 15-17].

In this work, polyurethanes were obtained using two nonaromatic diisocyanates (HDI and IPDI) and two kinds polyester polyols (PCL and PA). In these syntheses, the BD chain extender, used in a previous work [14], now has been replaced by ethylene glycol (EG), which should increase the film's hydrophilicity, and it is favorably beneficial for improving the mechanical properties of the obtained films and at the same time maintaining their good hydrolytic resistance. We are aware of some reservations regarding EG toxicity, but it concerns mainly the monomeric form of this diol or its polymeric varieties as polyoxyethylene diols [18]. EG as a polymer chain extender is not present as a monomer in PUs, but it is permanently bound in the high molecular form of urethane. However, this may affect the cytotoxicity in the long run when polyurethane hydrolysis occurs. We feel that examining this aspect is the novelty of this work, because it will resolve doubts about the use of EG as a component of polyurethane biomaterial. Before carrying out in vitro cytotoxicity studies, it was necessary to confirm the expected chemical structure and physical form of the polymers obtained. Research by GPC chromatography were helpful for correlating the molecular weight as well as FTIR determinations of the degrees of phase separation with the mechanical properties of the produced films. The obtained results are the next step toward developing new polyurethane materials for medical applications.

\section{Experimental part}

\section{Reagents and methods}

Hexamethylene diisocyanate (1,6-diisocyanatohexane) (HDI)

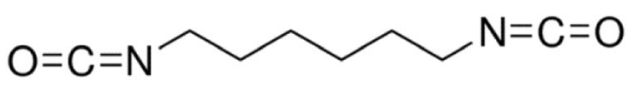

Isophorone diisocyanate (mixture of cis- and transisomers)

(3-Isocyanatomethyl-3,5,5-trimethylcyclohexyl isocyanate)

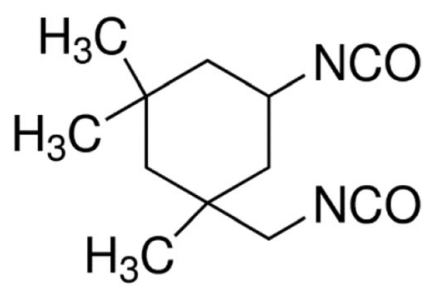


Diisocyanates were used as obtained from Aldrich.

Poly(ethylene adipate) diol (1000) (PA) was from Aldrich.<smiles>CC(C)OCCOC(=O)CCCCC(=O)C(C)(C)OCCO</smiles>

Poly $\left(\varepsilon\right.$-caprolactone) diol $(\mathrm{PCL})\left(M_{\mathrm{n}}=2000\right)$ was also from Aldrich.

*โ- $\left.\mathrm{O}-\left(\mathrm{CH}_{2}\right)_{5} \stackrel{\mathrm{II}}{\mathrm{C}} \frac{\mathrm{n}}{\mathrm{n}} \mathrm{O}-\mathrm{CH}_{2}-\mathrm{CH}_{2}-\mathrm{O}-\mathrm{CH}_{2}-\mathrm{CH}_{2}-\mathrm{O}-\stackrel{\mathrm{O}}{\mathrm{C}}-\left(\mathrm{CH}_{2}\right)_{5}-\mathrm{O}\right]_{\mathrm{n}}$ *

Ethylene glycol (EG)

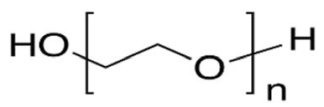

The low molecular weight volatiles including water were removed from PCL, PTMO, and ED by heating under vacuum, at $120{ }^{\circ} \mathrm{C}$, for $2-4 \mathrm{~h}$.

Dibutyl dilaurate tin (DBTL) was from Huntsman Performance Chemicals (used in very small quantities $(20 \mathrm{ppm}))$ as catalyst of the polyaddition reaction. The analytical reagents were as follows: dibutyloamine (Aldrich), $\mathrm{HCl}$ $0.1 \mathrm{~m}$ (POCh S.A. Poland), diiodomethane, formamide (Aldrich), redistilled water, and Baxter physiological saline (used in purchased form).

\section{Cell culture}

BJ human normal skin fibroblasts (ATCC, USA), doubling time of 1.9 days, were cultured in EMEM supplemented with $10 \%$ heat-inactivated FBS, $100 \mathrm{U} / \mathrm{mL}$ penicillin, and $100 \mu \mathrm{g} / \mathrm{mL}$ streptomycin. HaCaT human immortalized keratinocytes (CLS, Germany), doubling time of $24 \mathrm{~h}$, were propagated in a DMEM medium supplemented with $10 \% \mathrm{FBS}, 100 \mathrm{U} / \mathrm{mL}$ penicillin, $100 \mu \mathrm{g} /$ $\mathrm{mL}$ streptomycin. Cells were cultured at $37{ }^{\circ} \mathrm{C}$ in an atmosphere of $5 \% \mathrm{CO}_{2}$ and $95 \%$ humidity with growth medium changed every 2-3 days and passaged at $80 \%$ confluence, using $0.25 \%$ trypsin- $0.03 \%$ ethylenediaminetetraacetic acid in PBS (calcium- and magnesium-free). Cell morphology was checked under a Nikon TE2000S inverted microscope (Tokyo, Japan) equipped with phase contrast. The number and viability of cells were estimated by the trypan blue exclusion test, using Automatic Cell Counter TC20 ${ }^{\mathrm{TM}}$ (Bio-Rad Laboratories, Hercules, CA, USA).

\section{Method for the synthesis of polyurethane films}

The PU samples were synthesized in a two-stage polyaddition process in a glass laboratory set: three-necked flask, heating bowl, mechanical stirrer, dropping funnel, thermometer, reflux condenser, and nozzle for nitrogen supply. Previously dehydrated PCL or PA polyester heated to liquid form was dosed at $80^{\circ} \mathrm{C}$ during $1 \mathrm{~h}$ to the appropriate amount of HDI or IPDI diisocyanate; $0.01 \mathrm{wt} \%$ DBTL catalyst was added to the polyester immediately before synthesis. After this time, the content of unreacted -NCO groups was determined by asymmetric method using butyldiamine. The results similar to those expected in Table 1 were obtained. Then, the amount of EG was introduced to ensure an equimolar final ratio of $\mathrm{NCO} / \mathrm{OH}$ groups in the resulting reaction mixture, and the extending reaction of the prepolymer at $80{ }^{\circ} \mathrm{C}$ was continued until gelation of the reaction mixture began (about $1 \mathrm{~h}$ ). The amounts of reagents in subsequent syntheses are given Table 1 . The gelling polyurethane mass was introduced into a hot metal form with a 1.5-mm gap and was dragged over the teflon (PTFE) plate to form a film. If necessary, the viscosity was lowered by adding a small amount of tetrahydrofurane. The resulting films were placed in a vacuum dryer at $80{ }^{\circ} \mathrm{C}$ for $15 \mathrm{~h}$ to finally react the functional groups. The resulting films were conditioned at $20{ }^{\circ} \mathrm{C}$ for 10 days in air. Prior to testing, the films were gently removed from the PTFE plate.

\section{Infrared spectroscopy}

The FTIR spectra were recorded using a Nicolet iS10 (Thermo Scientific) Fourier transform spectrophotometer equipped with a diamond ATR unit. In all cases, 16 scans at a resolution of $4 \mathrm{~cm}^{-1}$ were collected to record the spectra in the range of $4000-650 \mathrm{~cm}^{-1}$.

By measuring the peak area of the hydrogen-bonded $\mathrm{C}=\mathrm{O}$ group at ca. $1694-1712 \mathrm{~cm}^{-1}$ from urethanes and of the free urethane $\mathrm{C}=\mathrm{O}$ group at ca. $1711-1730 \mathrm{~cm}^{-1}$, it is possible to estimate the degree of hydrogen bonding in the synthesized PU. The degree of the carbonyl groups participating in hydrogen bonding can be described by the carbonyl hydrogen bonding index $R$ that is given in Eq. (6):

$R=\frac{C_{\text {bonded }} \cdot f \text { bonded }}{C_{\text {free }} \cdot f_{\text {free }}}=\frac{A_{1694-1712}}{A_{1711-1730}}$

where $C$ is the concentration, $A$ is the area of the absorption peak, and $f$ is the respective extinction coefficient of the bonded and free carbonyl groups. The ratio of $f_{\text {bonded }} / f_{\text {free }}$ was taken as 1 according to Seymour et al. [19]. The degree of phase separation (DPS) index was calculated using Eq. (7):

DPS $=\frac{C_{\text {bonded }}}{C_{\text {free }}+C_{\text {bonded }}}=\frac{R}{1+R}$ 
Table 1 Chemical composition of the synthesized PUs

\begin{tabular}{lllll}
\hline Sample no. & PU-1 & PU-2 & PU-3 & PU-4 \\
\hline Type of diisocyanate & HDI $(M=168.2)$ & IPDI $(M=222.3)$ \\
Mass of diisocyanate, g & 10.00 & & & \\
Number of moles & 0.059 & & 0.045 & \\
Type of polyol & PCL & PA & PCL & PA \\
Mass of polyol, g & 60 & 30 & 45 & 22.5 \\
Number of moles & 0.030 & 0.030 & 0.0225 & 0.0225 \\
The ratio NCO/OH groups before adding EG & $2: 1$ & & & \\
Content of the $-\mathrm{NCO}$ groups, before adding EG, wt $\%$ & 3.60 & 6.29 & 3.44 & 5.81 \\
Mass of EG (M=61.07), g & 1.83 & 1.83 & 1.37 & 1.37 \\
Number of moles & 0.030 & & 0.023 & \\
Mass of sample & 71.83 & 41.83 & 56.37 & 33.87 \\
Content of the hard segments, wt\% in PU & 16.5 & 28.3 & 20.2 & 33.6 \\
$R$ & 0.350 & 0.110 & 1.201 & 0.536 \\
DPS & 0.259 & 0.099 & 0.546 & 0.349 \\
Mechanical properties & & & & \\
$\sigma_{\mathrm{r},}$ MPa & 13.30 & 2.10 & 3.34 & 1.80 \\
$\varepsilon_{\mathrm{r}}, \%$ & 688 & 15.8 & 13.4 & 59.3 \\
$E, \mathrm{MPa}$ & 2.50 & 47.2 & 115 & 49.1 \\
\hline
\end{tabular}

To calculate the degree of hydrogen bonding $(R)$ and the DPS, absorption bands in the range of $1650-1800 \mathrm{~cm}^{-1}$ have been deconvoluted to find the area of absorption bands at ca. 1709 and $1730 \mathrm{~cm}^{-1}$ that are connected to hydrogen-bonded and free carbonyl groups. The deconvolution of these bands is shown in Fig. 1.

\section{NMR spectrometry}

${ }^{1} \mathrm{H}$ and ${ }^{13} \mathrm{C}$ NMR spectra of the obtained PUs were taken with the use of the FT NMR Bruker Avance $500^{\mathrm{II}}$ spectrometer. The samples of films were dissolved in DMSO- $\mathrm{d}_{6} / \mathrm{h}-\mathrm{DMSO}$ and the solutions with the concentration of about $0.2 \mathrm{~g} / \mathrm{dm}^{3}$ were prepared. TMS was used as a standard.

\section{Gel permeation chromatography}

The molecular mass distribution of the polyurethane elastomers was measured by gel permeation chromatography (GPC), using RI detector (Shodex RI-71). The GPC instrument was equipped with Polymer Standards Services GPC column SDV $1000 \AA$ with SDV Guard column. The measurements were performed at the temperature of $22{ }^{\circ} \mathrm{C}$. All samples were dissolved in tetrahydrofuran (THF) of HPLC grade. The flow rate of the carrier solvent was $1.00 \mathrm{~mL} / \mathrm{min}$. Sample injection volume was $100 \mu \mathrm{L}$. The average molecular masses, $M_{\mathrm{n}}, M_{\mathrm{w}}$, and dispersity $M_{\mathrm{w}} / M_{\mathrm{n}}$ were determined by OmniSEC software. Polystyrene standards were used to make the calibration curve. Measurements were made for both polyurethane films and PU samples prepared especially in THF or 1,4-dioxane solutions at a concentration of about $5 \%$ by weight and precipitating the polymer from a solution of water.

\section{Diffraction analysis}

The phase composition of the samples was identified using an X-ray diffractometer Miniflex II from Rigaku Company. A filtered copper lamp $\left(\mathrm{Cu} K_{\alpha}, \lambda=0.154051 \mathrm{~nm}\right)$, with a voltage of $40 \mathrm{kV}$, range $2 \theta=3-100^{\circ}$, and step size $0.02^{\circ} / 1 \mathrm{~s}$, was used. Phase composition was determined using the Powder Diffraction File developed and issued by the ICDD (The International Center for Diffraction Data).

\section{Differential scanning calorimetry}

The calorimeter (DSC 1, Mettler-Toledo) was equipped with intracooler, as well as with STARe software for the control of the experimental conditions and for data analysis. The instrument was used to perform conventional DSC analyses and TOPEM measurements. For conventional measurements, the heating rate was $10 \mathrm{~K} / \mathrm{min}$. The sample mass was ca. $6 \mathrm{mg}$ and the atmosphere was nitrogen $(30 \mathrm{~mL} / \mathrm{min})$.

\section{Free surface energy}

The physical parameters of the free surface energy (FSE) of a solid $\gamma_{\mathrm{S}}$ were found on the basis of the Owens-Wendt 

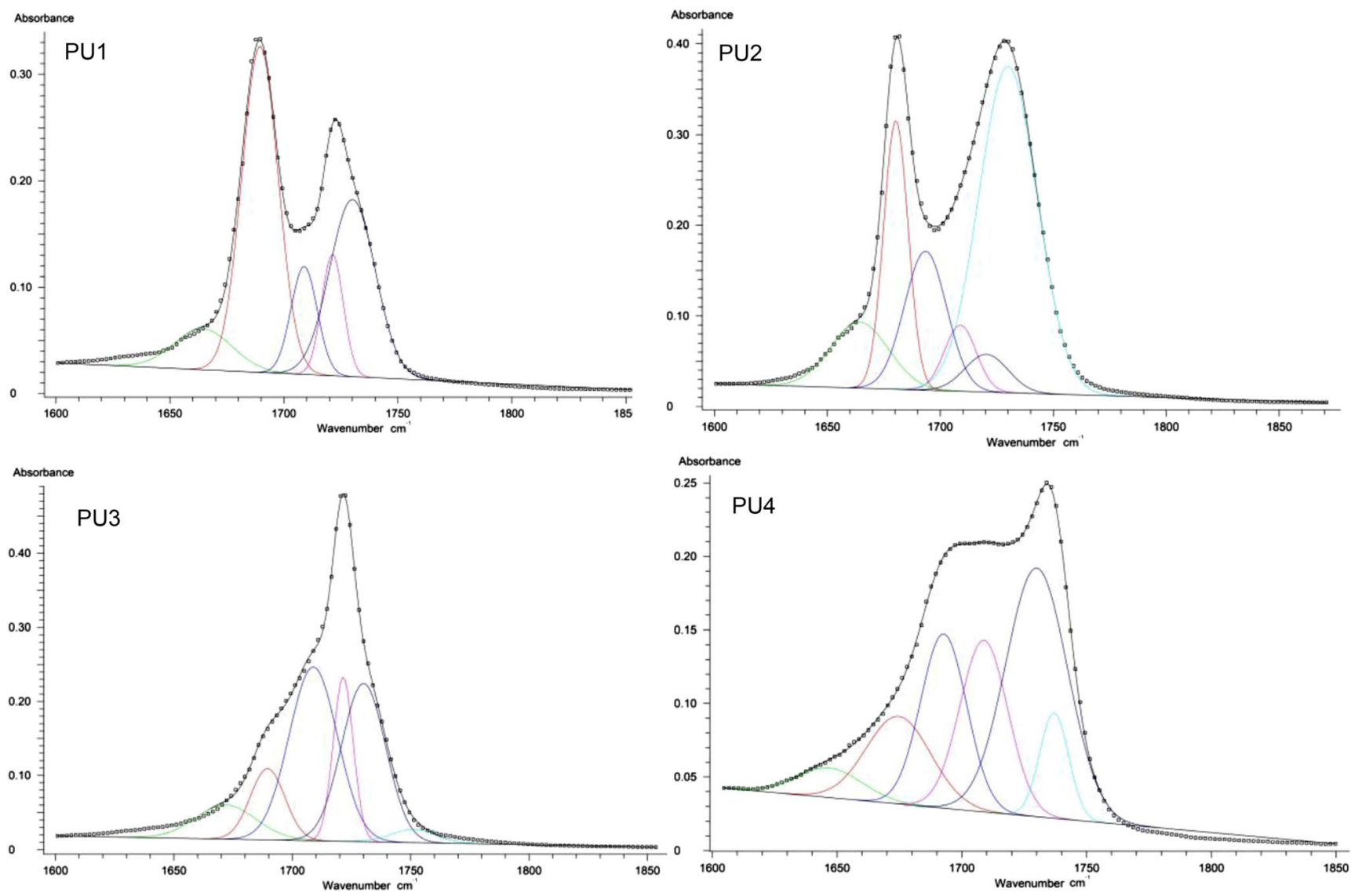

Fig. 1 Deconvolution of absorption C=O IR bands of PU-1-PU-4 samples

methods. The method assumes that the FSE $\left(\gamma_{\mathrm{S}, \mathrm{L}}\right)$ may be presented as a sum of two components [20]:

$\gamma_{\mathrm{S}, \mathrm{L}}=\gamma_{\mathrm{S}, \mathrm{L}}^{\mathrm{d}}+\gamma_{\mathrm{S}, \mathrm{L}}^{\mathrm{p}}$

where

$\gamma_{\mathrm{S}, \mathrm{L}}^{\mathrm{d}}$ - surface energy connected with dispersion interactions

$\gamma_{\mathrm{S}, \mathrm{L}}^{\mathrm{p}}$ - surface energy connected with polar interactions

For water: $\gamma_{\mathrm{L}}=72.8, \gamma_{\mathrm{L}}^{\mathrm{d}}=21.8, \gamma_{\mathrm{L}}^{\mathrm{p}}=51.0 \mathrm{~mJ} / \mathrm{m}^{2}$.

For diiodomethane: $\gamma_{\mathrm{L}}=50.8, \gamma_{\mathrm{L}}^{\mathrm{d}}=48.5, \gamma_{\mathrm{L}}^{\mathrm{p}}=2.3 \mathrm{~mJ} / \mathrm{m}^{2}$ by $[20]$.

Equation (8) is generally applicable both to a solid phase (the subscript " $\mathrm{S}$ " is used then) as well as to a wetting liquid (standard liquid with the subscript "L").

The FSE for solids (S) and for liquids (L) interacting with those solids should fulfill the Owens-Wendt equation:

$\gamma_{L} \cdot \frac{1+\cos \Theta}{2}=\sqrt{\gamma_{S}^{d} \cdot \gamma_{L}^{d}}+\sqrt{\gamma_{S}^{p} \cdot \gamma_{L}^{p}}$

where $\Theta$ is the experimentally found contact angle between a liquid drop and a solid surface under investigation. Therefore, wetting angles $\Theta$ were first measured for the surfaces of polyurethane films with the use of model liquids (waterdiiodomethane) with the known parameters $\gamma_{\mathrm{L}}, \gamma_{\mathrm{L}}^{\mathrm{d}}$, and $\gamma_{\mathrm{L}}^{\mathrm{p}}$ (Table 6). Then, Eq. (9) was used to calculate the values $\gamma_{S}^{\mathrm{p}}$ and $\gamma_{\mathrm{S}}^{\mathrm{d}}$ for the studied polyurethane films. The $\gamma_{\mathrm{S}}$ values were calculated from Eq. (8).

The $\Theta$ contact angles were measured with the use of the method suggested by Zisman [21], i.e., by an optical goniometer (Cobrabid Optica, Warsaw) with a digital camera installed in the axial extension of its lens. Calculations of SEP parameters were made on the basis of the average $\Theta$ value obtained from 10 droplet images of a given liquid (diiodomethane, formamide, and redistilled water).

\section{Measurement of the mechanical properties}

Mechanical properties were determined according to PN-EN ISO 527-3:1998 using Instron 5967 testing machine. All specimens (100 $\mathrm{mm}$ long and $10 \mathrm{~mm}$ wide) were tested at a speed of $100 \mathrm{~mm} / \mathrm{min}$. The following parameters were determined: Young's modulus $(E)$, stress at break $\left(\sigma_{\mathrm{r}}\right)$, and elongation at break $\left(\varepsilon_{\mathrm{r}}\right)$. 
Fig. $2{ }^{1} \mathrm{H}$ NMR spectrum of the PU-1 sample

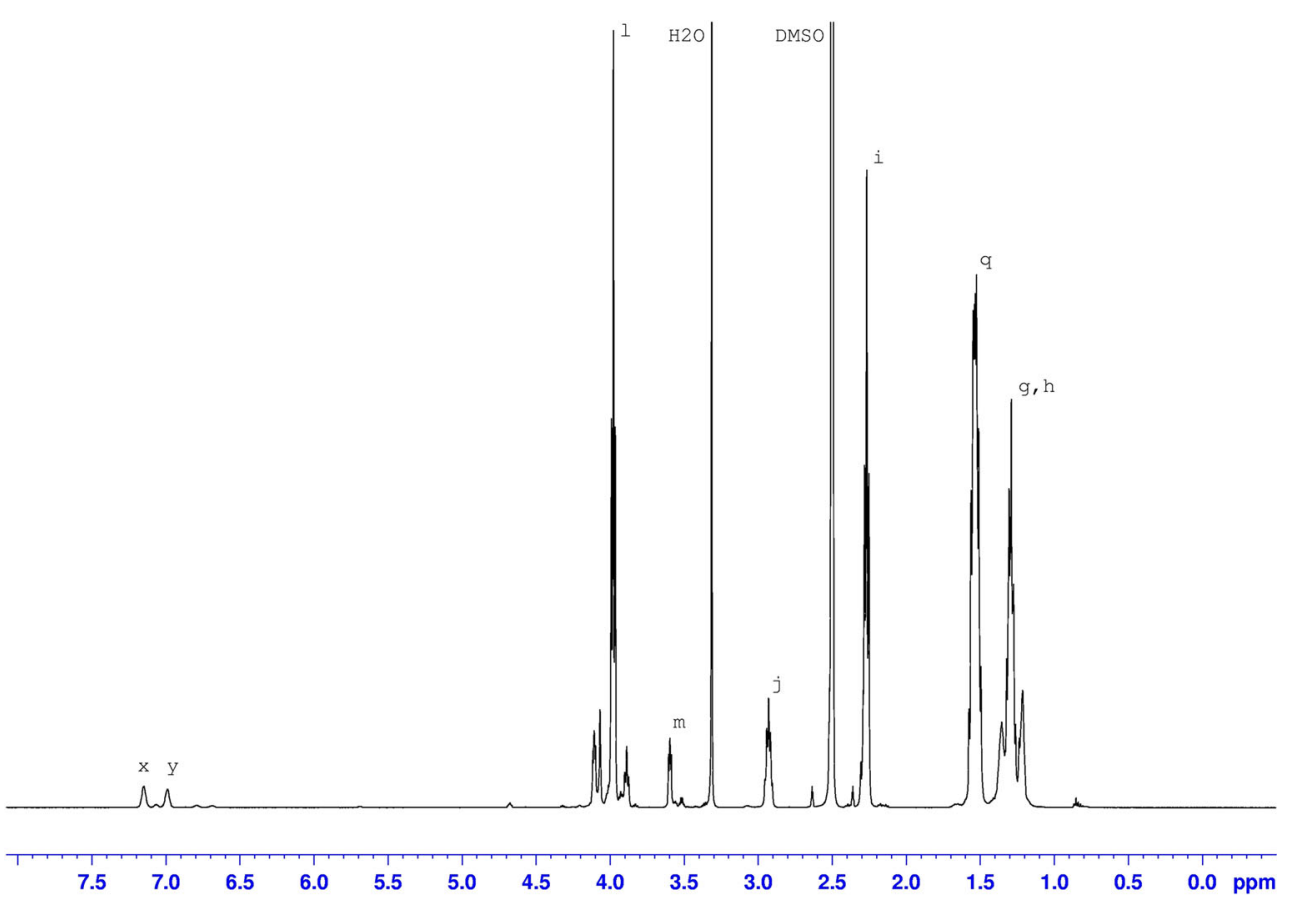

distillated water and dried in a nitrogen stream at $40{ }^{\circ} \mathrm{C}$, and determined for changes in their mass $(\%)$.

\section{The microbial biodegradation}

To determine the ability of the samples [22], they were dispensed in a test tube and sterilized by autoclaving. After
Fig. $3{ }^{13} \mathrm{C}$ NMR spectrum of the PU-1 sample

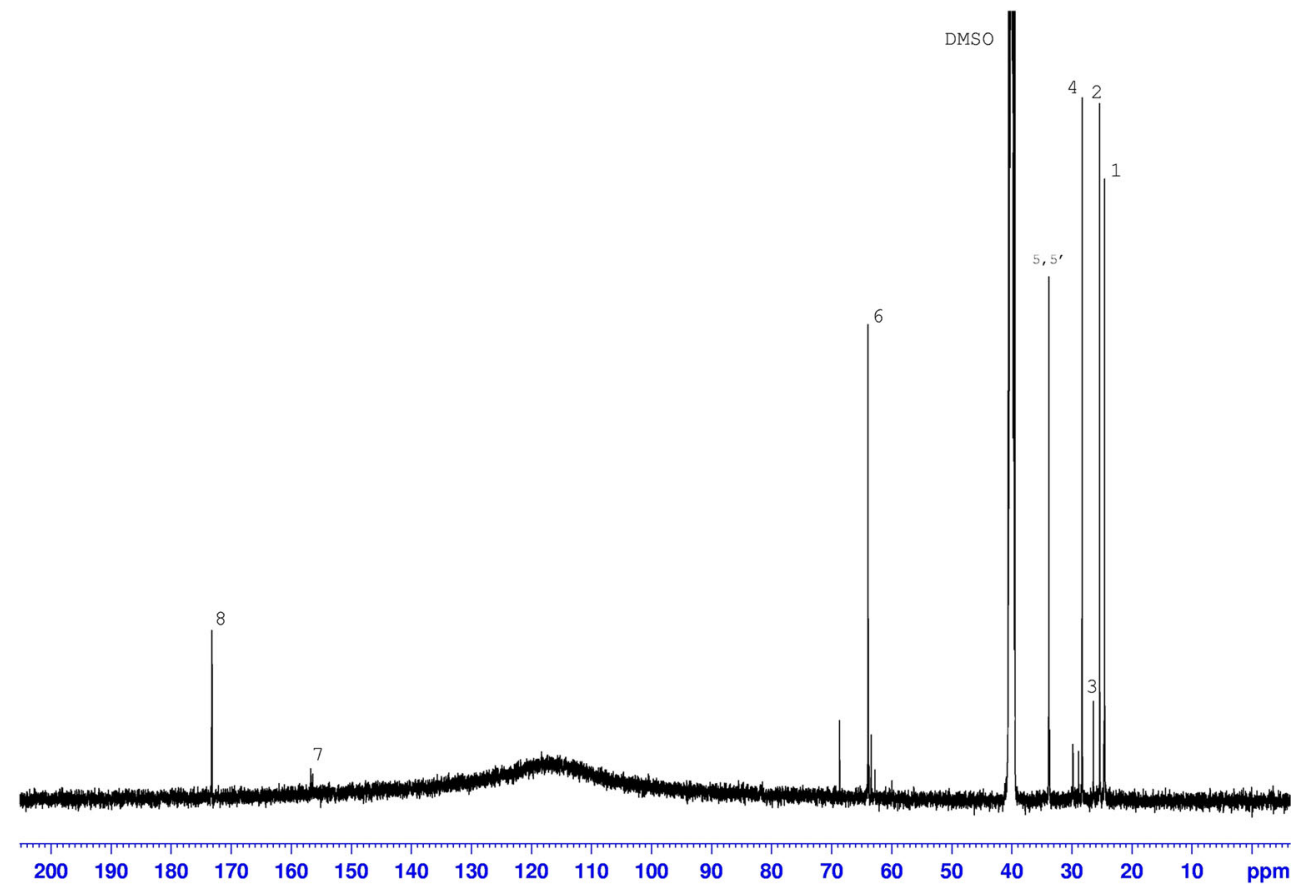


Fig. $4{ }^{1} \mathrm{H}$ NMR spectrum of the PU-4 sample

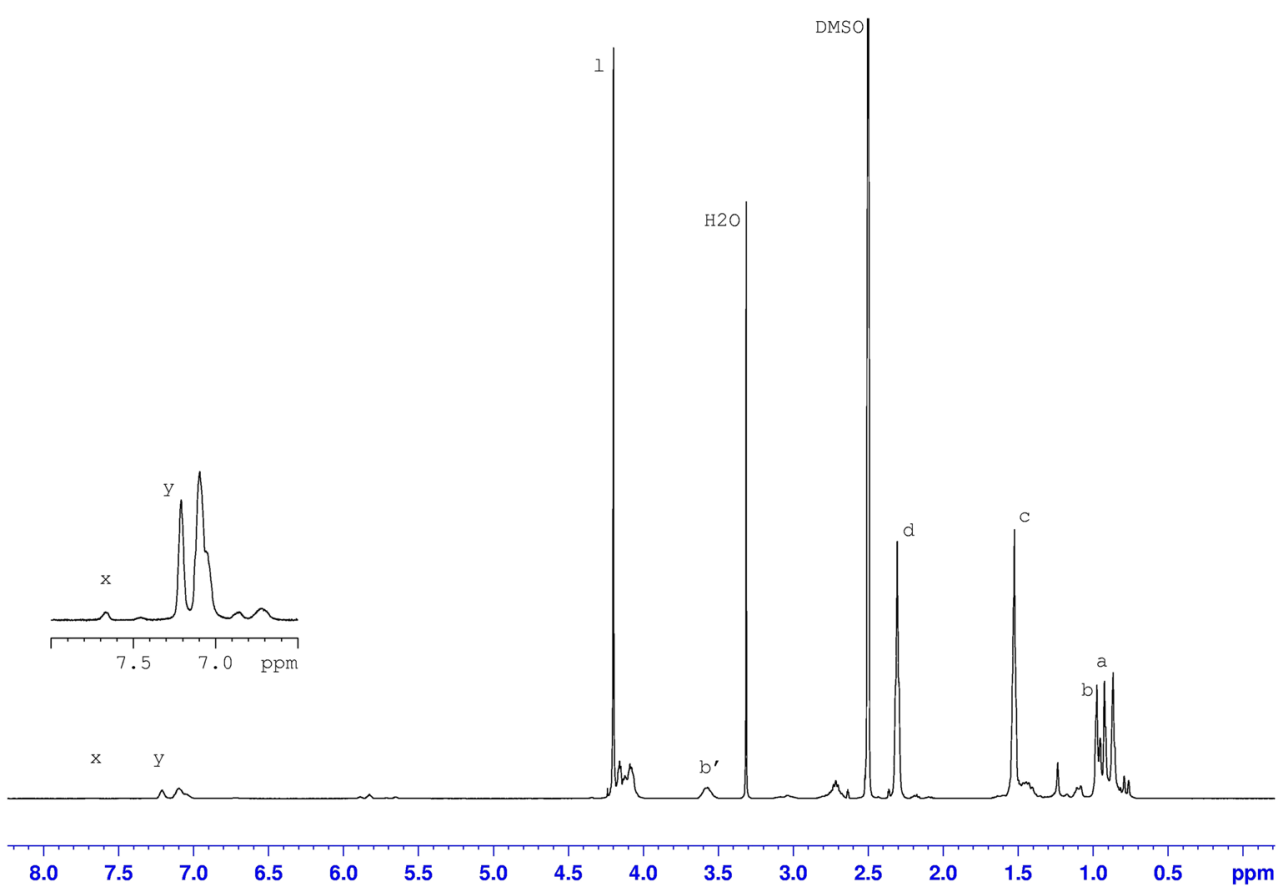

sterilization, the tubes were supplemented with appropriate PU sample (disinfected $30 \mathrm{~min}$ in $70 \%$ ethanol), inoculated with $10 \mu \mathrm{L}$ of overnight culture of bacterial isolate (Bacillus sp. MSP4 or Pseudomonas sp. MSP8), and incubated in a shaker (120 rpm) at $37^{\circ} \mathrm{C}$ for 19 days. The control was made by inoculating a tube containing mineral salt medium without any source of carbon. The degradation ability of the tested bacterial strains was determined by measuring the optical density (OD) of the liquid culture in a spectrophotometer at $600 \mathrm{~nm}$.

\section{Cytotoxicity studies}

Cytotoxicity of polyurethane films was examined as described in a previous work [14] using direct contact toxicity test. Normal human fibroblasts (BJ) and immortalized keratinocytes
Fig. $5{ }^{13} \mathrm{C}$ NMR spectrum of the PU-4 sample

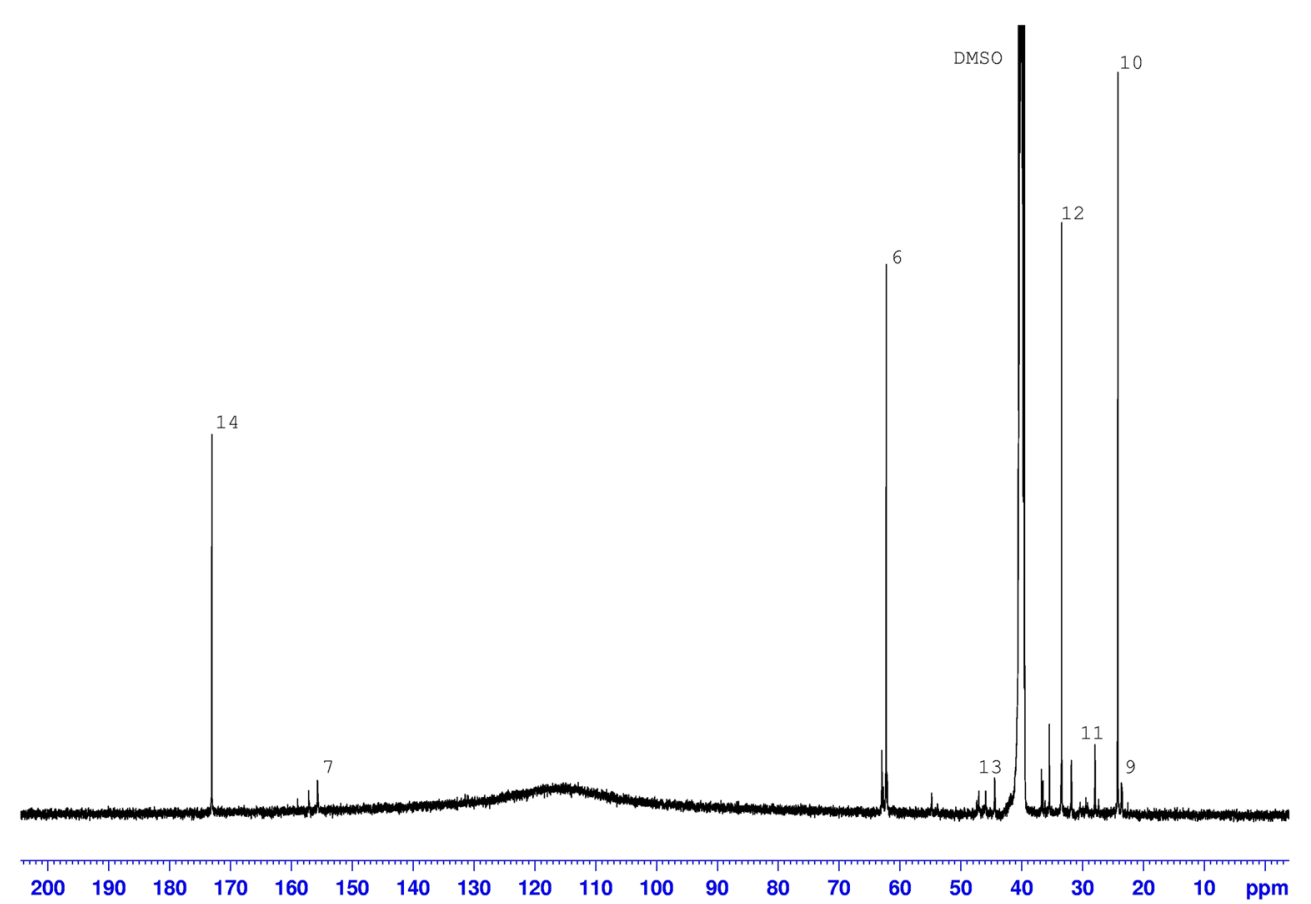




$$
\begin{aligned}
& \left(-A_{1}-B_{1}-A_{1}\right) B_{1}-E-B_{1}-\text { in } P U-1 \text { sample } \\
& \left(-A_{2}-B_{1}-A_{2}\right)_{n} B_{1}-E-B_{1}-\text { in PU-2 sample } \\
& \left(-A_{1}-B_{2}-A_{1}\right)_{n} B_{2}-E-B_{2}-\text { in PU-3 sample } \\
& \left(\mathrm{A}_{2}-\mathrm{B}_{2}-\mathrm{A}_{2}\right) \mathrm{B}_{2}-\mathrm{E}-\mathrm{B}_{2}-\text { in } \mathrm{PU}-4 \text { sample } \\
& \text { where: }
\end{aligned}
$$

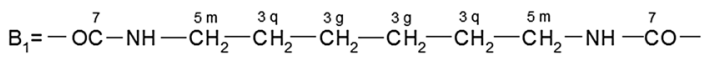

$$
\begin{aligned}
& \mathrm{B}_{2}=\stackrel{9 \mathrm{a}}{\mathrm{C}} \mathrm{CH}_{3}-\stackrel{11}{\mathrm{C}}-\stackrel{11 \mathrm{~b}}{\mathrm{C}} \mathrm{H}_{2} \backslash \stackrel{13}{\mathrm{C}} \mathrm{H}-\mathrm{HH}-\stackrel{7}{\mathrm{C} O}-
\end{aligned}
$$

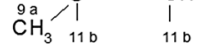

$$
\begin{aligned}
& \mathrm{CH}_{2}^{11}, \mathrm{CH}_{2}^{11 b}
\end{aligned}
$$

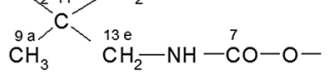

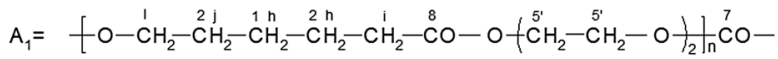

$$
\begin{aligned}
& \mathrm{A}_{2}=-\mathrm{O}-\stackrel{8}{\mathrm{C}} \mathrm{O}-\stackrel{\mathrm{d}}{\mathrm{CH}_{2}}-\stackrel{10 \mathrm{C}}{\mathrm{C}}-\stackrel{10 \mathrm{C}}{\mathrm{C}} \mathrm{H}_{2}-\stackrel{\mathrm{d}}{\mathrm{C}}-\stackrel{8}{\mathrm{C}}-\mathrm{O}-\mathrm{O}-\stackrel{\mathrm{e}}{\mathrm{e}}_{2}-\mathrm{CH}_{2}^{\prime}-\mathrm{O}-\stackrel{7}{\mathrm{C} O}-\mathrm{NH}- \\
& \mathrm{E}=-\mathrm{O}-\stackrel{6}{\mathrm{C}} \mathrm{H}_{2}-\stackrel{6}{\mathrm{C}} \mathrm{H}_{2}-\mathrm{O}-
\end{aligned}
$$

Scheme 1 Structures of the synthesized polyurethanes

$(\mathrm{HaCaT})$ were seeded $\left(4 \times 10^{5}\right.$ and $8 \times 10^{5}$ cells/well, respectively) into 6-well plates and incubated $\left(24 \mathrm{~h}, 37{ }^{\circ} \mathrm{C}, 5 \% \mathrm{CO}_{2}\right.$, $95 \%$ humidity). After that, fresh media with $10 \%$ FBS $(800 \mu \mathrm{L}$ per well) were added and sterilized with ethylene oxide gas. PU samples with a flat surface $(10 \times 10 \mathrm{~mm}, 1 \mathrm{~mm}$ thickness $)$ were placed on cell monolayer and incubated for $24 \mathrm{~h}$. High-density polyethylene (HDPE) specimen was used as a control. After removing and washing with $\mathrm{PBS}$, the specimens were stained with $0.2 \%$ crystal violet in $2 \%$ ethanol for $30 \mathrm{~min}$. After washing with water $(3 \times)$, only undamaged, adherent, stained cells were present on the plate surface. Then, images of plates with stained cells were collected and the reactivity zones were measured with ImageJ software (U.S. National Institutes of Health, Bethesda, MD, USA) as distances from the edge of specimens. Obtained results were interpreted by the grade of the reactivity zone described by the U.S. Pharmacopeial Convention [23]. In the next step, solubilization of stained cells was performed on a shaker $(800 \mu \mathrm{L} /$ well of $10 \%$ acetic acid, $10 \mathrm{~min}, 400 \mathrm{rpm}, \mathrm{RT})$. The absorbance of CV solutions from the individual sample cells was measured at $595 \mathrm{~nm}$ against $450 \mathrm{~nm}$ against a blank sample (10\% acetic acid) ( $\mu$ Quant $^{\mathrm{TM}}$, BioTek Instruments, Inc. Winooski, VT, USA). Results were presented as a percentage of control. All experiments were performed in triplicate.

\section{Statistical analysis}

\begin{tabular}{|c|c|c|c|c|}
\hline $\begin{array}{l}\text { Sample } \\
\text { no. }\end{array}$ & $\begin{array}{l}\text { Chemical } \\
\text { shift } \\
\delta, \text { ppm }\end{array}$ & Type of protons & $\begin{array}{l}\text { Marking } \mathrm{H} \\
\text { atom } \\
\text { according to } \\
\text { Scheme } 1\end{array}$ & $\begin{array}{l}\text { The origin of } \\
\text { the fragment } \\
\text { structure } \\
\text { (scheme 1) }\end{array}$ \\
\hline PU-1 & $1.213-1.321$ & $-\mathrm{NH}-\mathrm{CH}_{2}-\mathrm{CH}_{2}-\left(\underline{\mathrm{CH}_{2}}\right)_{2}-\mathrm{CH}_{2}-\mathrm{CH}_{2}-\mathrm{NH}-$ & g & HDI \\
\hline PU-1 & & $-\left[\mathrm{O}-\mathrm{CH}_{2}-\left(\underline{\mathrm{CH}_{2}}\right)_{3}-\mathrm{CH}_{2}-\mathrm{CO}\right]_{n}-\mathrm{O}-\left(\mathrm{CH}_{2}\right)_{2}-\mathrm{O}-$ & $\mathrm{h}$ & PCL \\
\hline PU-1 & $1.495-1.576$ & $-\mathrm{NH}-\mathrm{CH}_{2}-\underline{\mathrm{CH}_{2}}-\left(\mathrm{CH}_{2}\right)_{2}-\underline{\mathrm{CH}_{2}}-\mathrm{CH}_{2}-\mathrm{NH}$ & q & HDI \\
\hline $\begin{array}{l}\text { PU-1, } \\
\text { PU-2 }\end{array}$ & 2.5 & $\left(\underline{\mathrm{CH}_{3}}\right)_{2} \mathrm{SO}$ & & DMSO \\
\hline PU-1 & $2.253-2.291$ & $-\left[\mathrm{O}-\mathrm{CH}_{2}-\left(\mathrm{CH}_{2}\right)_{3}-\underline{\mathrm{CH}_{2}}-\mathrm{CO}\right]_{n}-\mathrm{O}-\left(\mathrm{CH}_{2}\right)_{2}-\mathrm{O}-$ & $\mathrm{i}$ & PCL \\
\hline PU-1 & 2917-2942 & $-\left[\mathrm{O}-\mathrm{CH}_{2}-\underline{\mathrm{CH}_{2}}-\left(\mathrm{CH}_{2}\right)_{2}-\mathrm{CH}_{2}-\mathrm{CO}\right]_{n}-\mathrm{O}-$ & $\mathrm{j}$ & PCL \\
\hline PU-1 & 3.3 & & & $\mathrm{H}_{2} \mathrm{O}$ \\
\hline PU-1 & $3.888-4.117$ & $-\mathrm{NH}-\mathrm{CO}-\mathrm{O}-\left(\underline{\mathrm{CH}_{2}}\right)_{2}-\mathrm{O}-\mathrm{CO}-\mathrm{NH}-$ & 1 & $\begin{array}{l}\text { (HDI or IPDI) }+ \\
\quad \text { EG }\end{array}$ \\
\hline PU-1 & $3.587-3.605$ & $-\mathrm{NH}-\underline{\mathrm{CH}_{2}}-\left(\mathrm{CH}_{2}\right)_{4}-\underline{\mathrm{CH}_{2}}-\mathrm{NH}-\mathrm{CO}-\mathrm{O}-$ & $\mathrm{m}$ & HDI \\
\hline PU-4 & $0.924-0.974$ & $\underline{\mathrm{CH}_{3}}-\mathrm{C}$ & $\mathrm{a}$ & IPDI \\
\hline PU-4 & $1.081-1.172$ & $-\mathrm{CH}_{2}-$ in pos. $2,6,4$ & $\mathrm{~b}$ & $\begin{array}{l}\text { IPDI } \\
\text { cyclohexane } \\
\text { ring }\end{array}$ \\
\hline PU-4 & $1.235-1.525$ & $-\mathrm{O}-\mathrm{CO}-\mathrm{CH}_{2}-\mathrm{CH}_{2}-\underline{\mathrm{CH}_{2}}-\underline{\mathrm{CH}_{2}}-\mathrm{CH}_{2}-\mathrm{CO}-\mathrm{O}$ & $\mathrm{c}$ & PA \\
\hline PU-4 & $2.306 ; 2.362$ & $\mathrm{O}-\mathrm{CO}-\underline{\mathrm{CH}_{2}}-\mathrm{CH}_{2}-\mathrm{CH}_{2}-\mathrm{CH}_{2}-\underline{\mathrm{CH}_{2}}-\mathrm{CO}-\mathrm{O}$ & d & PA \\
\hline \multirow[t]{2}{*}{ PU-4 } & $\approx 3.5$ & $\begin{array}{l}\mathrm{C}-\underline{\mathrm{CH}_{2}}-\mathrm{NH}-\mathrm{CO}-\mathrm{O}-\text { in pos. } 3 \\
\mathrm{CH}_{2}-\underline{\mathrm{CH}}-\mathrm{NH}-\mathrm{CO}-\mathrm{O}-\text { in pos. } 1\end{array}$ & $\mathrm{~b}^{\prime}$ & $\begin{array}{l}\text { IPDI } \\
\text { cyclohexane } \\
\text { ring }\end{array}$ \\
\hline & & $-\left[\mathrm{O}-\left(\mathrm{CH}_{2}\right)_{4}-\mathrm{CO}\right]_{n}-\mathrm{O}-\left(\underline{\mathrm{CH}_{2}}\right)_{2}-\mathrm{O}-$ & $\mathrm{e}$ & PA \\
\hline \multirow[t]{2}{*}{ PU-4 } & $4.079-4.239$ & $-\mathrm{NH}-\mathrm{CO}-\mathrm{O}-\underline{\mathrm{CH}_{2}}-\underline{\mathrm{CH}_{2}}-\mathrm{O}-\mathrm{OC}-\mathrm{NH}-$ & & $\mathrm{IPDI}+\mathrm{EG}$ \\
\hline & & $-\mathrm{NH}-\mathrm{CO}-\mathrm{O}-\underline{\mathrm{CH}_{2}}-\underline{\mathrm{CH}_{2}}-\mathrm{O}-\mathrm{OC}-\underline{\left(\mathrm{CH}_{2}\right)_{4}}-$ & & $\mathrm{IPDI}+\mathrm{PA}$ \\
\hline
\end{tabular}

Statistical analysis was performed with Statistica 12.5 software (StatSoft). Nonparametric Kruskal-Wallis test
Table $2{ }^{1} \mathrm{H}$ NMR spectra interpretation of the PU-1 and PU-4 samples 
Table $3 \mathrm{C}^{13}$ NMR spectrum interpretation of the PU-1 and PU-4 samples

\begin{tabular}{|c|c|c|c|c|}
\hline $\begin{array}{l}\text { Sample } \\
\text { no. }\end{array}$ & $\begin{array}{l}\text { Chemical shift } \\
\text { of C } \\
\delta, \mathrm{ppm}\end{array}$ & Type of carbons & $\begin{array}{l}\text { Marking C } \\
\text { atom according } \\
\text { to Scheme } 1\end{array}$ & $\begin{array}{l}\text { The origin of the } \\
\text { fragment structure } \\
\text { (Scheme 1) }\end{array}$ \\
\hline PU-1 & $24.505-24.633$ & $\begin{array}{l}-\mathrm{O}-\mathrm{CH}_{2}-\mathrm{CH}_{2}-\underline{\mathrm{CH}_{2}}-\mathrm{CH}_{2}-\mathrm{CH}_{2}-\mathrm{CO}- \\
-\mathrm{O}-\mathrm{CH}_{2}-\underline{\mathrm{CH}_{2}}-\mathrm{CH}_{2}-\underline{\mathrm{CH}_{2}}-\mathrm{CH}_{2}-\mathrm{CO}-\end{array}$ & $\begin{array}{l}1 \\
2\end{array}$ & $\begin{array}{l}\text { PCL } \\
\text { PCL }\end{array}$ \\
\hline PU-1 & $25.3315-26.409$ & $-\mathrm{O}-\mathrm{CH}_{2}-\left(\underline{\mathrm{CH}_{2}}\right)_{3}-\mathrm{CH}_{2}-\mathrm{NH}-\mathrm{CO}-$ & 3 & HDI \\
\hline PU-1 & $28.271-29.852$ & $-\mathrm{O}-\mathrm{CH}_{2}-\mathrm{CH}_{2}-\mathrm{CH}_{2}-\mathrm{CH}_{2}-\underline{\mathrm{CH}_{2}}-\mathrm{CO}-$ & 4 & PCL \\
\hline $\begin{array}{l}\text { PU-1, } \\
\text { PU-4 }\end{array}$ & 40 & $\left(\underline{\mathrm{CH}_{3}}\right)_{2} \mathrm{SO}$ & & DMSO \\
\hline PU-1 & $33.727-33.878$ & $\begin{array}{l}-\mathrm{O}-\mathrm{CH}_{2}-\left(\mathrm{CH}_{4}\right)_{3}-\underline{\mathrm{CH}_{2}}-\mathrm{NH}-\mathrm{CO}- \\
-\left(\mathrm{CH}_{2}\right)_{5}-\mathrm{CO}-\mathrm{O}-\underline{\mathrm{CH}_{2}}-\underline{\mathrm{CH}_{2}}-\mathrm{O}-\mathrm{CO}-\end{array}$ & $\begin{array}{l}5 \\
5^{\prime}\end{array}$ & $\begin{array}{l}\text { HDI } \\
\text { PKL }\end{array}$ \\
\hline $\begin{array}{l}\text { PU-1, } \\
\text { PU-4 }\end{array}$ & $62.789-68.687$ & $-\mathrm{NH}-\mathrm{CO}-\mathrm{O}-\underline{\mathrm{CH}_{2}}-$ & 6 & $\begin{array}{l}\text { (HDI or IPDI) }+ \\
\text { EG } \\
(\mathrm{HDI} \text { or IPDI) }+ \\
(\mathrm{PCL} \text { or PA })\end{array}$ \\
\hline $\begin{array}{l}\text { PU-1, } \\
\text { PU-4 }\end{array}$ & $155-158$ & $-\mathrm{NH}-\underline{\mathrm{CO}}-\mathrm{O}-$ & 7 & $\begin{array}{l}\text { Urethane from } \\
\text { HDI or IPDI }\end{array}$ \\
\hline PU-1 & 173.202 & $-\mathrm{O}-\mathrm{CH}_{2}-\underline{\mathrm{CH}_{2}}-\mathrm{CH}_{2}-\underline{\mathrm{CH}_{2}}-\mathrm{CH}_{2}-\underline{\mathrm{CO}}-$ & 8 & PCL \\
\hline PU-4 & $23.487-23.601$ & $-\mathrm{CH}_{3}$ & 9 & IPDI \\
\hline PU-4 & 24.196 & $-\mathrm{CO}-\underline{\mathrm{CH}_{2}}-\underline{\mathrm{CH}_{2}}-\underline{\mathrm{CH}_{2}}-\mathrm{CH}_{2}-\underline{\mathrm{CO}}-$ & 10 & PA \\
\hline PU-4 & $27.376-27.947$ & $\mathrm{C}, \mathrm{CH}, \mathrm{CH}_{2}$ in pos. $2,3,4,5,6$ & 11 & $\begin{array}{l}\text { IPDI cyclohexane } \\
\text { ring }\end{array}$ \\
\hline PU-4 & $31.760 ; 31.854$ & $-\mathrm{O}-\mathrm{CH}_{2}-\left(\mathrm{CH}_{2}\right)_{3}-\underline{\mathrm{CH}_{2}}-\mathrm{CO}-$ & 12 & PA \\
\hline PU-4 & $44.44-47.054$ & $\begin{array}{l}-\underline{\mathrm{CH}}-\mathrm{NH}-\mathrm{CO}-\text { in pos. } 1 \\
-\underline{\mathrm{CH}}_{2}-\mathrm{NH}-\mathrm{CO}-\end{array}$ & 13 & $\begin{array}{l}\text { IPDI cyclohexane } \\
\text { ring } \\
\text { IPDI }\end{array}$ \\
\hline PU-4 & 173.025 & $-\mathrm{CH}_{2}-\mathrm{CO}-\mathrm{O}-\mathrm{CH}_{2}-$ & 14 & PA \\
\hline
\end{tabular}

(with post hoc comparisons of mean ranks for all groups) was used to estimate differences between samples incubated with different PUs and between samples incubated with PUs and control. Paired Mann-Whitney $U$ test was used to evaluate the differences between BJ and $\mathrm{HaCaT}$ cells treated with the same samples of PUs. $P \leq 0.05$ was regarded as statistically significant.

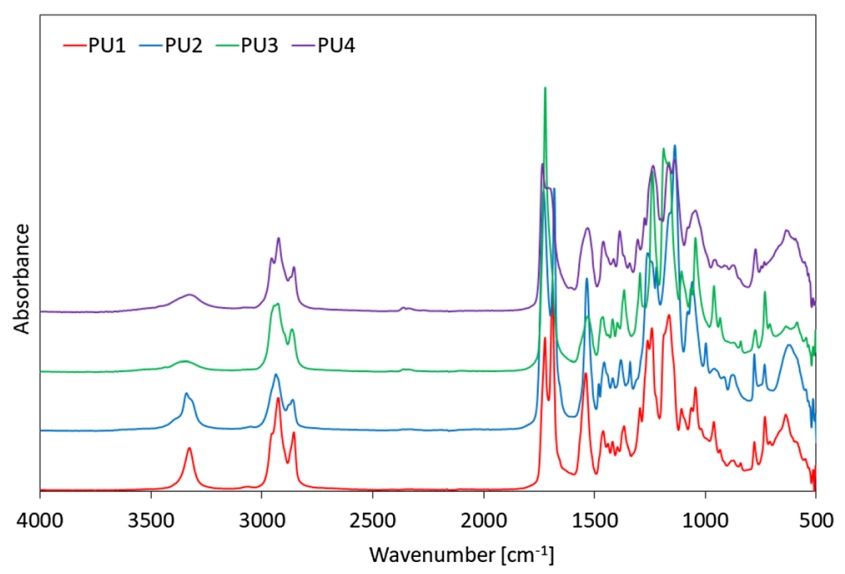

Fig. 6 FTIR spectra for the synthesized PUs

\section{Results and discussion}

\section{Analysis of the structure and phase of the prepared polyurethane films}

All recorded NMR spectra confirm the expected structures of synthesized polyurethanes. For simplicity, this article presents

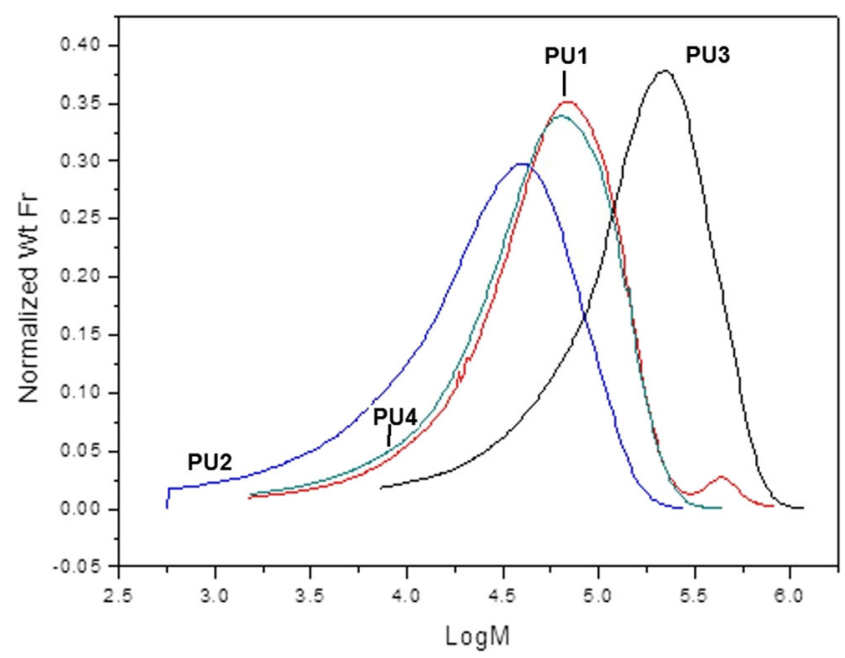

Fig. 7 Molar mass distribution of the synthesized PUs 
Table 4 Molecular weights and dispersity of the synthesized polyurethane

\begin{tabular}{lrrrrr}
\hline Sample no. & \multicolumn{1}{l}{$M_{\mathrm{n}}$} & \multicolumn{1}{l}{$M_{\mathrm{w}}$} & \multicolumn{1}{l}{$M_{\mathrm{z}}$} & \multicolumn{1}{l}{$M_{\mathrm{p}}$} & $M_{\mathrm{w}} / M_{\mathrm{n}}$ \\
\hline PU-1 & 27,500 & 74,780 & 150,120 & 69,580 & 2.71 \\
PU-2 & 9780 & 36,660 & 65,100 & 39,750 & 3.74 \\
PU-3 & 87,850 & 203,240 & 306,970 & 221,950 & 2.31 \\
PU-4 & 24,380 & 6470 & 99,690 & 64,920 & 2.60 \\
\hline
\end{tabular}

a detailed interpretation of only PU-1 and PU-4 samples. Exemplary NMR spectra of PU-1 and PU-4 samples are provided in Figs. 2, 3, 4, and 5, on which the specific resonances $\mathrm{H}$ (marked with the letter) and $\mathrm{C}$ (marked with the number) are presented in Scheme 1. The detailed interpretation of the ${ }^{1} \mathrm{H}$ and ${ }^{13} \mathrm{C}$ NMR spectra is presented in Tables 2 and 3.

Analysis of the FTIR spectra of the obtained PUs (Fig. 6) revealed the bands at $3340 \mathrm{~cm}^{-1}$ can be attributed to $\mathrm{N}-\mathrm{H}$ group stretching vibrations and the double absorption bands at 1720$1690 \mathrm{~cm}^{-1}$ can be assigned to vibrations in $\mathrm{C}=\mathrm{O}$ groups. The lack of a band at $2260 \mathrm{~cm}^{-1}$ for all the studied PUs confirmed complete conversion of the isocyanate reagents.

A characteristic feature of PU linear elastomers is the limited miscibility of hard urethane segments made of diisocyanate and low molecular weight diol and flexible long polyol segments. This is the result of a significant difference in the polarity of these structures. The factors favoring phase homogeneity are strong interactions resulting from the presence of hydrogen bonds. $\mathrm{C}=\mathrm{O}$ groups present in the hard and soft segments (from polyester structures) and $\mathrm{O}$ atoms in soft segments are acceptors, and the formed urethane groups are donors of these bonds. The conformation of hard and soft segment chains is also important. $\mathrm{R}$ and DPS parameters obtained after deconvolution of the absorption bands of $\mathrm{C}=\mathrm{O}$ groups in the range of $1650-1800 \mathrm{~cm}^{-1}$ allow interpretation concerning the tendency of phase separation in the tested PUs. As it can be seen in Table 1, both the degree of hydrogen bonding (R) and the DPS strongly depend on the PU composition. The change of isocyanate from HDI to IPDI leads to an increase of DPS both PUs based on PCL and PA soft segments. It can be linked with better miscibility (also busier) of aliphatic-derived linear hard segments with soft polyester segments, compared to cyclic rigid isocyanates. On the other hand, the changing of the polyol from PCL to PA causes a reduction of R and DPS parameters for PU obtained from both HDI and IPDI. This effect may be the result of a smaller number of acceptor centers resulting from a lower molecular weight of PA segments.

The molecular weight distribution (MWD) curves of the synthesized PU obtained from GPC measurements are shown in Fig. 7, and the appropriate numerical parameters are given in Table 4.

The MWD parameters of the studied PUs are 2.313.74 and are much wider than in the case of PUs synthesized by $\mathrm{H}_{12} \mathrm{MDI}(1.45-1.90)$ [14]. The highest mass average molar mass as well as the lowest dispersion was found for PU-3. The stated $M_{\mathrm{w}} \approx 200,000$ value should be considered unexpectedly large even compared to PU1 previously synthesized from $\mathrm{H}_{12} \mathrm{MDI}$ and $\mathrm{PCL}$ $(120,600)$, especially since IPDI isocyanate has primary and secondary $-\mathrm{NCO}$ groups. As you can see, the PCL linear structure was critical. High values of R and DSP parameters are an important factor conditioning the presence of a significant number of hydrogen bonds in PU-3, which should favor the formation of a crystalline phase in this sample. The results of WAXS measurements are presented in Fig. 8. Based on X-ray diffraction patterns, it was found that the PU films designated as PU-1, PU-2,
Fig. 8 WAXD patterns of obtained polyurethane films

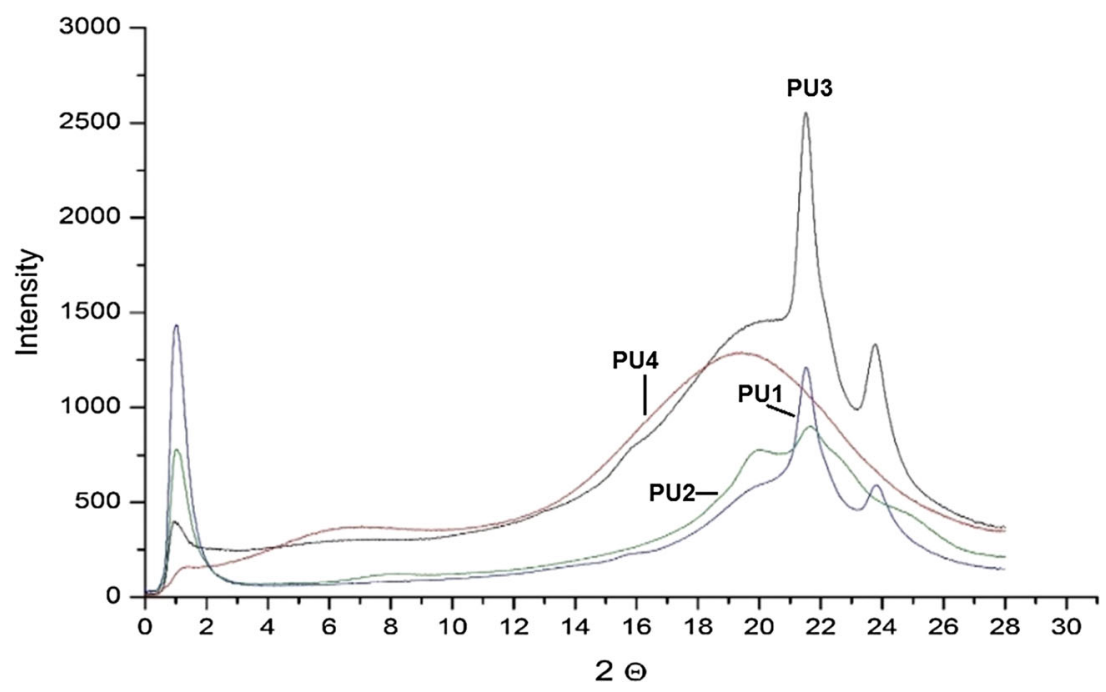



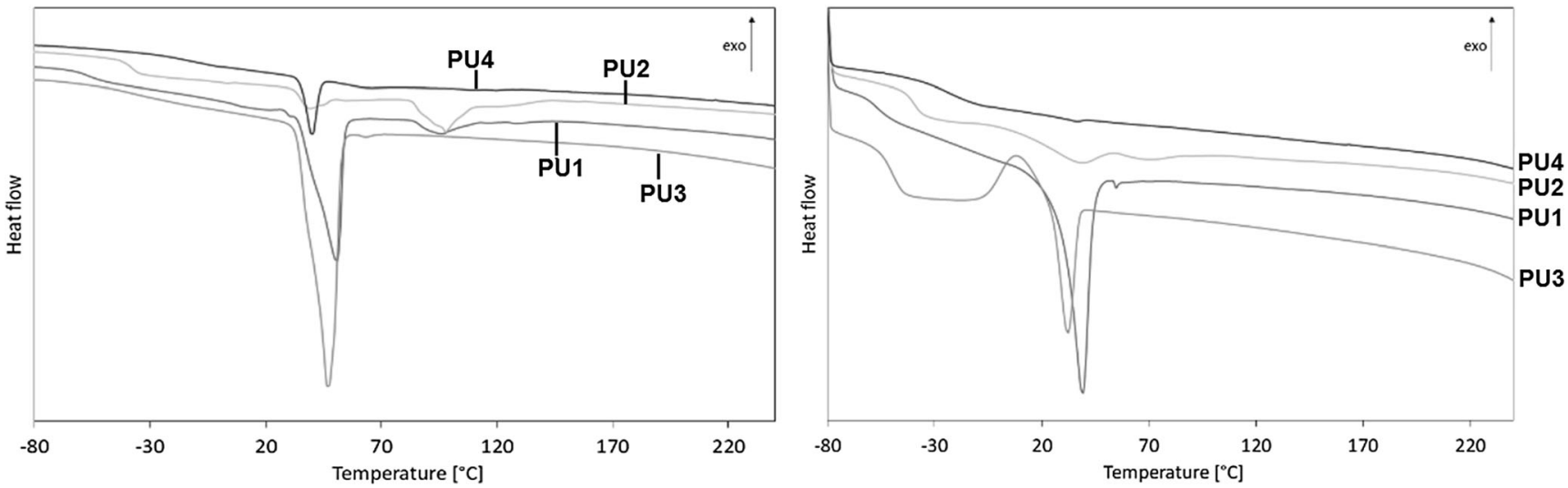

Fig. 9 DSC curves of obtained PU films: from the 1st heating run (left) and the 2nd heating run (right)

and PU-3 contain crystalline phases, while the PU-4 sample synthesized from IPDI and PA is mainly amorphous. This may be explained by the much lower molecular weight PA of the soft segment.

The main data on the structure of the phases of the films producing results from the DSC measurements are presented on Fig. 9 and Table 5.

DSC thermograms confirm the WAXS results about the amorphous structure of PU-4 film. In other films, there are visible endo changes associated with melting of soft segments $\left(T_{\mathrm{m}}=30-50^{\circ} \mathrm{C}\right)$, but in PU-1 and PU-2 films, also in $T_{\mathrm{m}}=$ $95-98{ }^{\circ} \mathrm{C}$ of the hard segments. The change of isocyanate from HDI to IPDI leads to greater crystallization capacity, which can be observed in the changes in the melting heat of both the soft PCL and PA phases (from 39.9 for PU-1 to $65.2 \mathrm{~J} / \mathrm{g}$ for PU-3) and from $\approx 0$ up to $10 \mathrm{~J} / \mathrm{g}$ but only in the 1 st heating run in PU-2 and PU-3 films. The 2 nd heating run destroys this order and it is not rebuilt. PU-3 and PU-1 samples have the largest proportion of the crystalline phase, which is confirmed by both DSC analysis and WAXS X-ray. The observed effects are consistent with the values of R and DPS parameters, whose values for PUs with soft PCL segment are greater than their analogs based on PA segments and for both types of diisocyanates used.

The clearly visible presence of two phase transitions associated with discontinuous changes in specific heat indicates the heterogeneous phase structure of the synthesized polymers typical of PU elastomers: $T \mathrm{~g}_{1}<0$ refers to the transformation occurring in the segments of soft polyesters, and $\mathrm{Tg}_{2}>0$ in the transformation into hard urethane segments derived from diisocyanate and EG. Two such phase transitions visible in each tested sample show limited mutual miscibility of both types of segments. Rigid segments in PU are responsible for the durability of the structure of the tested materials, which provides them with the mechanical strength required for biomaterials. On the other hand, flexible segments contribute to a simultaneous increase in flexibility and also as structures that are more hydrophobic for better chemical resistance.

Table 5 DSC results for PU films

\begin{tabular}{|c|c|c|c|c|c|c|c|c|}
\hline \multirow[t]{2}{*}{$\begin{array}{l}\text { Sample } \\
\text { no. }\end{array}$} & \multicolumn{2}{|c|}{$\begin{array}{l}\text { Glass transition of soft } \\
\text { segments }\end{array}$} & \multicolumn{2}{|c|}{$\begin{array}{l}\text { Glass transition of } \\
\text { hard segments }\end{array}$} & \multicolumn{2}{|c|}{$\begin{array}{l}\text { Melting of soft } \\
\text { segments }\end{array}$} & \multicolumn{2}{|c|}{$\begin{array}{l}\text { Melting of hard } \\
\text { segments }\end{array}$} \\
\hline & $\begin{array}{l}T_{\mathrm{g} 1}, \\
{ }^{\circ} \mathrm{C}\end{array}$ & $\begin{array}{l}\Delta C_{\mathrm{p}}, \mathrm{kJ} / \\
\mathrm{mol} \text { deg }\end{array}$ & $\begin{array}{l}T_{\mathrm{g} 2}, \\
{ }^{\circ} \mathrm{C}\end{array}$ & $\begin{array}{l}\Delta C_{\mathrm{p}}, \mathrm{kJ} / \\
\mathrm{mol} \mathrm{deg}\end{array}$ & $\begin{array}{l}T_{\mathrm{m} 1}, \\
{ }^{\circ} \mathrm{C}\end{array}$ & $\begin{array}{l}\text { Heat of } \\
\text { fusion, } \mathrm{J} / \mathrm{g}\end{array}$ & $\begin{array}{l}T_{\mathrm{m} 2} \\
{ }^{\circ} \mathrm{C}\end{array}$ & $\begin{array}{l}\text { Heat of } \\
\text { fusion, } \mathrm{J} / \mathrm{g}\end{array}$ \\
\hline \multicolumn{9}{|c|}{1 st heating run } \\
\hline PU-1 & -56.7 & 0.306 & 7.1 & 0.167 & 50.3 & 39.9 & 95.7 & 5.1 \\
\hline PU-2 & -38.3 & 0.490 & 35.3 & 0.410 & - & - & 98.2 & 18.1 \\
\hline PU-3 & -35.7 & 0.374 & - & - & 46.6 & 65.2 & - & - \\
\hline PU-4 & -32.7 & 0.351 & - & - & 40.1 & 10.3 & - & - \\
\hline \multicolumn{9}{|c|}{2 nd heating run } \\
\hline PU-1 & -58.0 & 0.280 & - & - & 38.8 & 34.1 & - & - \\
\hline PU-2 & -39.4 & 0.500 & 27.9 & 0.510 & - & - & - & - \\
\hline PU-3 & -49.9 & 0.600 & - & - & 32.0 & 10.9 & - & - \\
\hline PU-4 & -23.9 & 0.601 & 33.8 & 0.018 & - & - & - & - \\
\hline
\end{tabular}


Table 6 Surface parameters of the PU films

\begin{tabular}{|c|c|c|c|c|c|}
\hline \multirow[t]{2}{*}{ Sample no. } & \multicolumn{2}{|c|}{$\begin{array}{l}\text { Contact angle },{ }^{\circ} \\
\text { Confidence interval }\end{array}$} & \multicolumn{3}{|c|}{$\begin{array}{l}\text { FSE parameters, } \mathrm{mJ} / \mathrm{m}^{2} \\
\text { Confidence interval }\end{array}$} \\
\hline & & & $\gamma_{\mathrm{S}}^{\mathrm{d}}$ & $\gamma_{\mathrm{S}}^{\mathrm{p}}$ & $\gamma_{\mathrm{s}}$ \\
\hline PU-1 & $\begin{array}{l}56.7 \\
\pm 3.5\end{array}$ & $\begin{array}{l}101.6 \\
\pm 2.5\end{array}$ & $\begin{array}{l}30.9 \\
\pm 0.8\end{array}$ & $\begin{array}{l}0.19 \\
\pm 0.1\end{array}$ & $\begin{array}{l}31.1 \\
\pm 0.8\end{array}$ \\
\hline PU-2 & $\begin{array}{l}25.9 \\
\pm 4.5\end{array}$ & $\begin{array}{r}83.7 \\
\pm 2.0\end{array}$ & $\begin{array}{l}44.1 \\
\pm 0.4\end{array}$ & $\begin{array}{l}1.7 \\
\pm 0.1\end{array}$ & $\begin{array}{l}45.8 \\
\pm 0.4\end{array}$ \\
\hline PU-3 & $\begin{array}{l}68.5 \\
\pm 2.5\end{array}$ & $\begin{array}{l}100.6 \\
\pm 2.3\end{array}$ & $\begin{array}{l}22.6 \\
\pm 1.2\end{array}$ & $\begin{array}{c}1.1 \\
\pm 0.3\end{array}$ & $\begin{array}{l}23.0 \\
\pm 1.2\end{array}$ \\
\hline PU-4 & $\begin{array}{l}32.1 \\
\pm 3.5\end{array}$ & $\begin{array}{r}81.4 \\
\pm 1.8\end{array}$ & $\begin{array}{l}40.5 \\
\pm 0.6\end{array}$ & $\begin{array}{c}2.9 \\
\pm 0.1\end{array}$ & $\begin{array}{l}43.4 \\
\pm 0.6\end{array}$ \\
\hline
\end{tabular}

\section{Surface properties}

Table 6 gives the determined values of contact angles of the tested PU films for 2 model liquids and calculated on the basis of measurements for 10 drops of the confidence interval values.

These results were used to calculate FSE parameters according to the van Oss-Good model. The determination of contact angles and FSE parameters showed that the polyester component had the greatest impact on the nature of the obtained films. PU-3 and PU-1 films synthesized with PCL polyester were more hydrophobic and their FSE was about $30 \mathrm{~mJ} / \mathrm{m}^{2}$. Films synthesized with the participation of PA polyester are definitely hydrophilic, and their FSE value is about $42 \mathrm{~mJ} / \mathrm{m}^{2}$. This is a significant difference. These differences can be explained by the apolar structure of PCL soft segments resulting from the presence of $-\left(\mathrm{CH}_{2}\right)_{5}-$ groups. The structure of the rigid diisocyanate segment derived from HDI or IPDI and EG is of lesser importance here. More hydrophobic films were obtained from PU synthesized from IPDI diisocyanate. This can be explained by the more hydrophobic nature and greater stiffness of the cyclohexane rings compared to the labile structure of the HDI chains. The dispersion component $\gamma_{S}^{\mathrm{d}}$ has a decisive share in the values of the $\gamma_{\mathbf{S}}$ parameters, which is due to the extensive structure of alkyl groups susceptible to this type of interaction. Polar impacts are definitely less important here. It should be noted that previously synthesized films based on $\mathrm{H}_{12}$ MDI diisocyanate and PCL or PTMG polyols and butanediol were more hydrophilic, and their FSE varied in the range of $35.9-44.9 \mathrm{~mJ} / \mathrm{m}^{2}$, and similarly, the lowest hydrophilicity showed a film containing soft PCL segments [14].
Fig. 10 Stretching curves $(\sigma-\varepsilon)$ of the formed polyurethane films

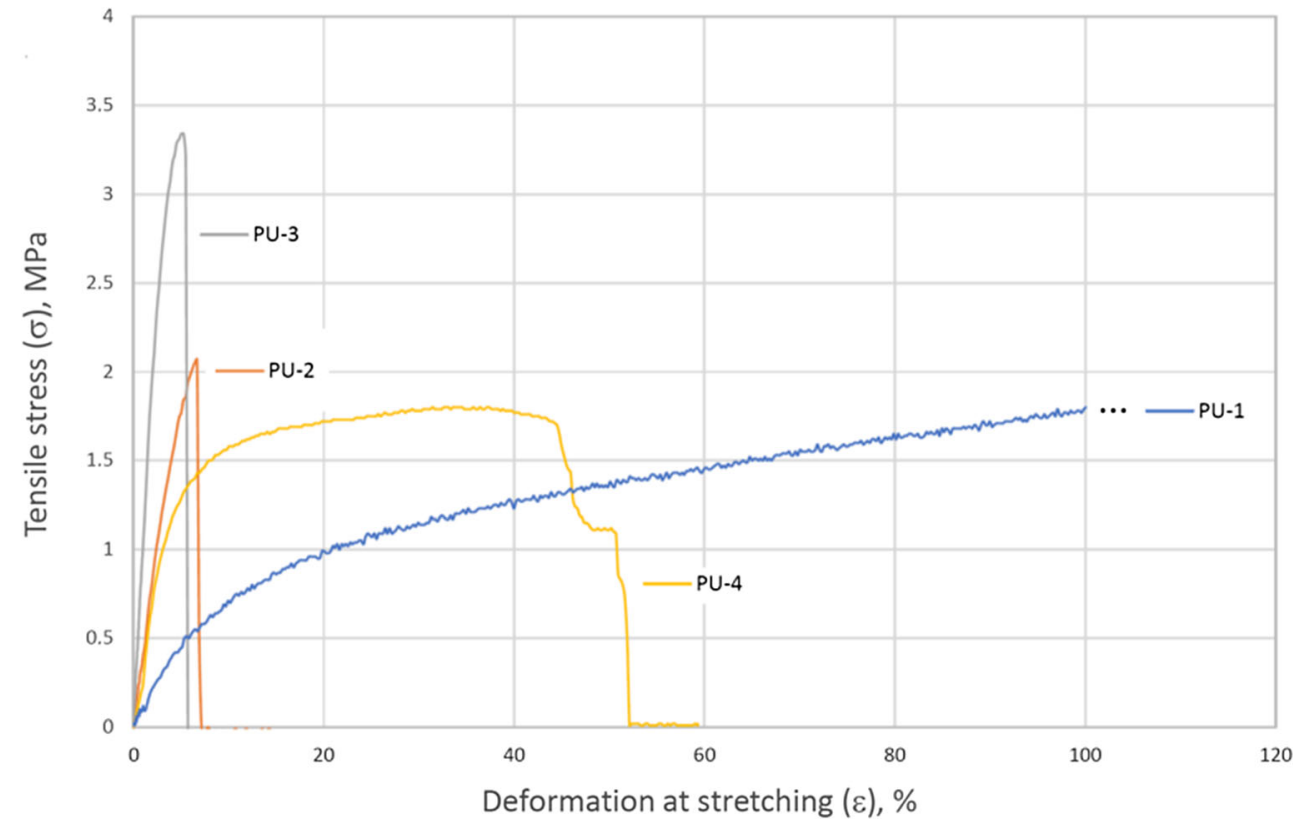




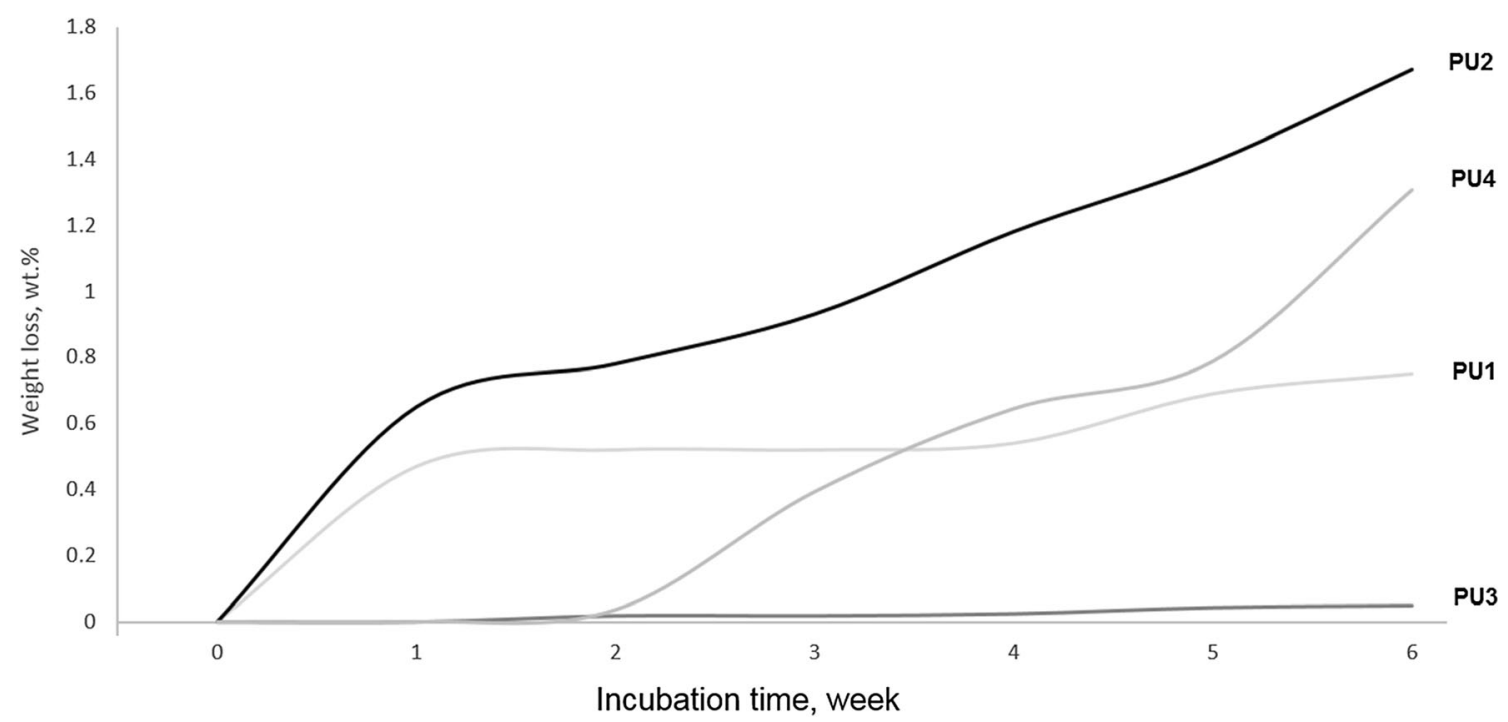

Fig. 11 Diagrams of sample mass changes during Baxter liquid incubation

\section{Mechanical properties}

The main mechanical parameters of the obtained films are given in Table 1. In Fig. 10, you can see a large discrepancy in the course of recorded $\sigma-\varepsilon$ curves. The results obtained indicate a decisive relationship between the film strength parameters and the chemical and phase structure of the polyurethane films. By changing the mass ratios of the reagents, it is possible to regulate the content of rigid and flexible segments, and thus affect the $\sigma_{\mathrm{r}}$ and $\varepsilon_{\mathrm{r}}$ parameters and the $E$ module. The PU-1 film containing only $16.5 \%$ of hard segments has properties similar to PU elastomer, but it is characterized by a low value of $E$ module. A significant phase separation resulting from strong hydrogen interactions causes stiffening of the structure and increase of $E$ module which is visible in PU-3 film. Other films are definitely more rigid, but less mechanically strong. The obtained mechanical properties do not allow direct use of these films as biomaterials. In this case, materials that are more mechanically durable are required ( $\sigma_{\mathrm{r}} \approx 30 \mathrm{MPa}$ and $\left.\varepsilon_{\mathrm{r}} \approx 500 \%\right)$ [24]. At this stage of research, it was important that the obtained mechanical properties enabled measurements of surface properties and biological tests of the synthesized materials.

\section{Hydrolytic resistance, microbial biodegradation, and cytotoxicity}

The hydrolytic resistance of polyurethane material in the environment of the human body is extremely important for biomedical applications. To pre-assess this property, the
Fig. 12 Growth $\left(\mathrm{OD}_{600}\right)$ of Bacillus sp. MSP4 and Pseudomonas sp. MSP8 on the 19th day after incubation in minimal mineral salt media supplemented with polyurethane sample (PU) as carbon source

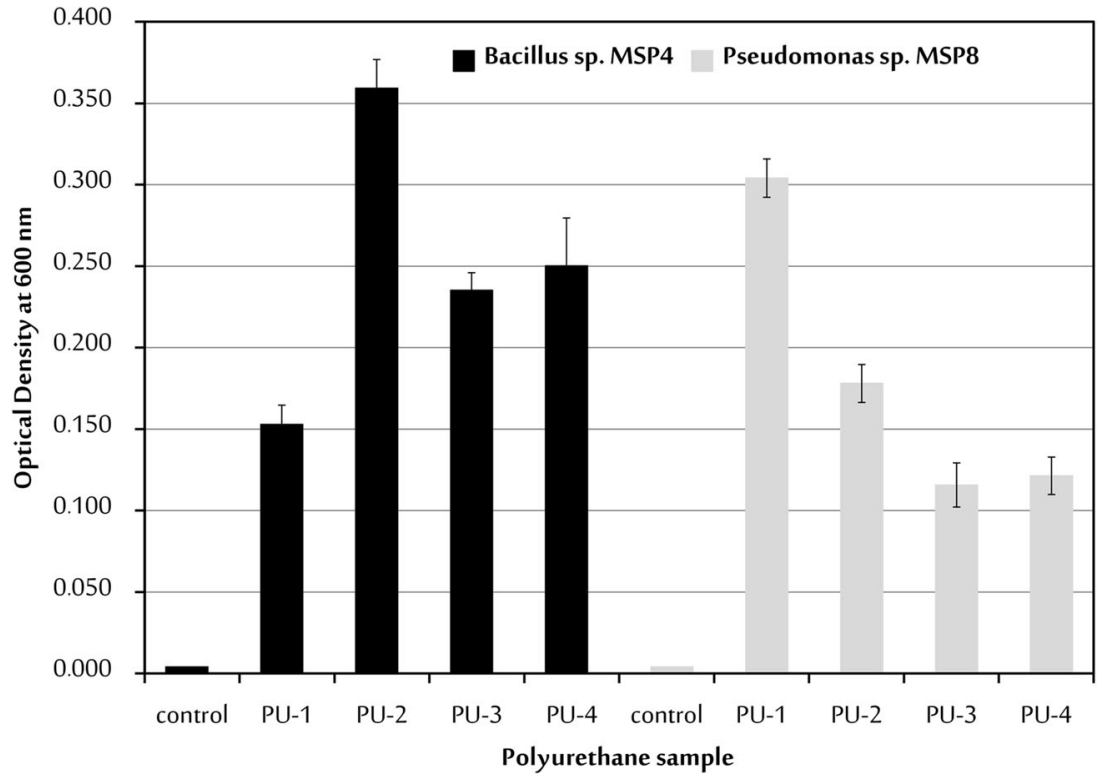


Fig. 13 Images of human fibroblasts (BJ) and immortalized keratinocytes $(\mathrm{HaCaT})$ stained with crystal violet after $24 \mathrm{~h}$ incubation with the studied PUs. The top and bottom rows show wells with stained cells. Squares indicate locations of examined samples. In the middle, images of cells from the reactivity zones
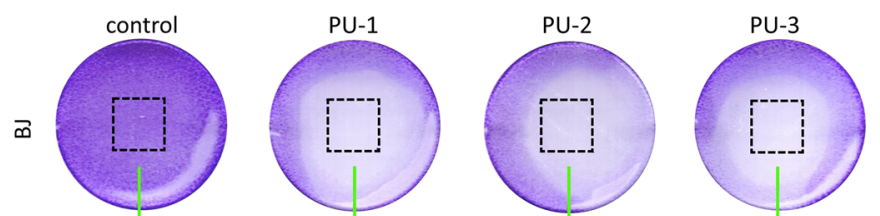

PU-4
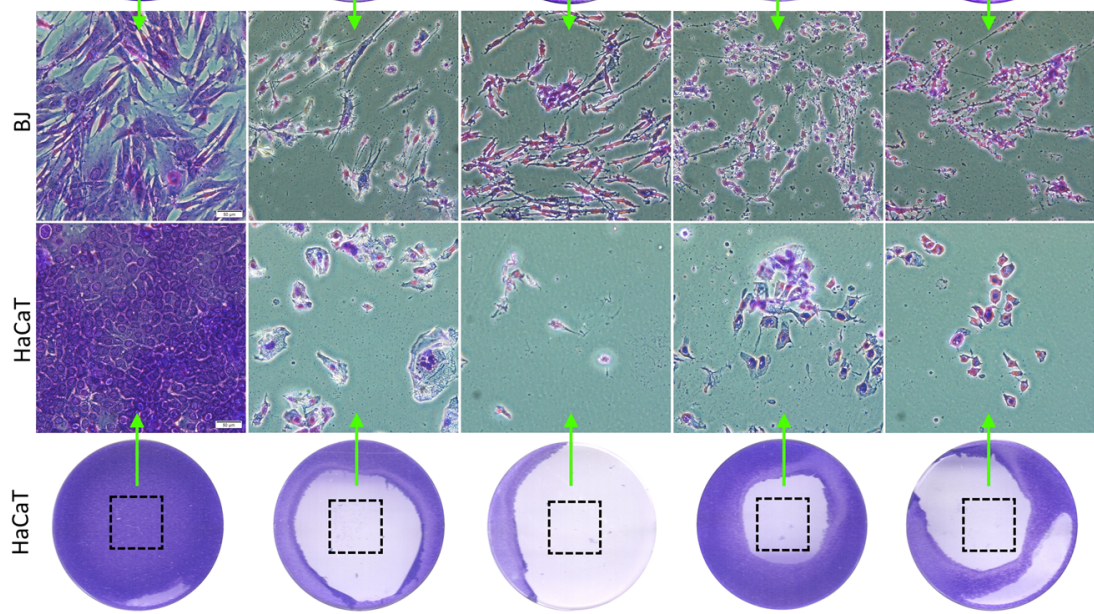

synthesized films were incubated in Baxter fluid for 6 weeks. The observed changes in mass of the test samples are presented in Fig. 11. As expected, films containing apolar soft PCL segments showed the highest hydrolytic resistance. The weight change of the PU-3 sample did not exceed $0.2 \mathrm{wt} \%$. In this case, it is necessary to take into account the relatively largest molecular weight of this sample, which determines the compactness of the polymer structure. Much lower resistance to hydrolysis was observed in films much more hydrophilic: PU-2 and PU-4 containing soft PA segments. Here, much larger weight losses above $1.5 \%$ were recorded. Literature reports suggest significant changes in the hydrolytic stability of polyurethanes only in the longer incubation period [15-17].

The microbial biodegradation of the synthesized polyurethanes was performed using culture turbidity as a qualitative measure of cell growth. Both Gram-positive (Bacillus sp.) and
Gram-negative (Pseudomonas sp.) types of bacterial strains were used to test the biodegradation property. The results, as shown in Fig. 12, indicated that all synthesized PUs are biodegradable, because both tested isolates were able to grow in a medium containing PUs as a sole source of carbon. Biodegradability differed between samples and depended on the bacterial strain used. The bacterial growth rate was the highest for the PU-2 (Bacillus sp. MSP4) and PU-1 (Pseudomonas sp. MSP8) samples.

\section{Cytotoxicity of PUs}

The medical device market contains a wide spectrum of products, from surgical instruments to blood bags and surgical gloves. Biocompatibility assessment is required for medical devices in order to minimize potential hazards to patients or
Fig. 14 Reactivity zone size (mm) after $24 \mathrm{~h}$ incubation of BJ and $\mathrm{HaCaT}$ cells with the PU samples (direct contact assay). Results are expressed as medians of twelve measurements from three independent assays. The lower $(25 \%)$ and upper (75\%) quartile ranges are presented as whiskers. Arrows indicate significant differences between samples $(P<0.05$, Kruskal-Wallis test) and $\boldsymbol{\nabla}$ significant differences between cell lines for the corresponding PU samples $(P<0.05$, Mann-Whitney $U$ test)

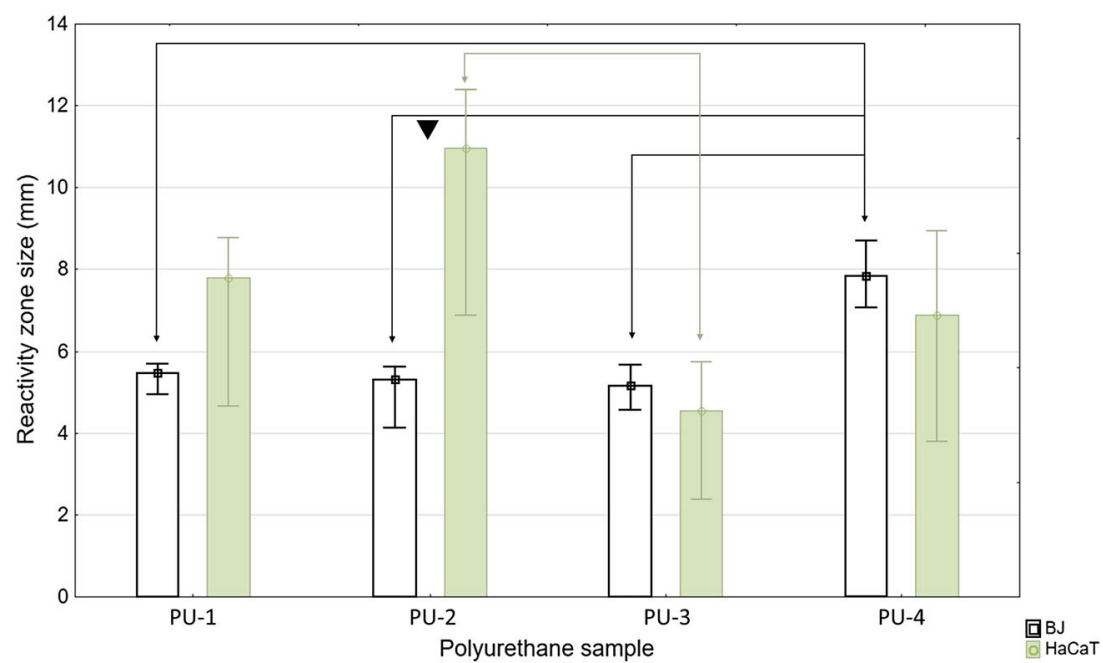


Fig. 15 Viability of BJ and $\mathrm{HaCaT}$ cells after $24 \mathrm{~h}$ incubation with PU samples estimated with direct contact assay (measuring the absorbance of crystal violet released from cells). Results expressed as medians (\% of control). The lower (25\%) and upper $(75 \%)$ quartile ranges are presented as whiskers. * Indicates significant differences against control and arrows between polyurethane samples $(P<0.05$, Kruskal-Wallis test). $\boldsymbol{\nabla}$ means significant differences between cell lines for the corresponding samples $(P<0.05$, MannWhitney $U$ test)

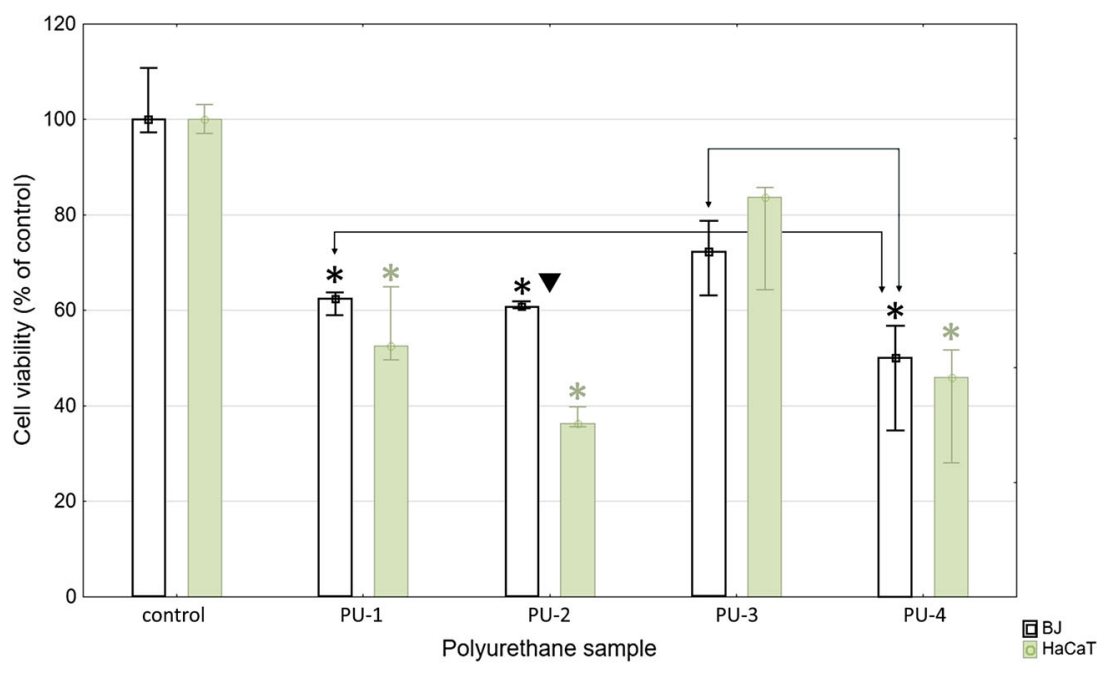

their users. Synthesized PUs utilized as materials for medical application were assessed with direct contact assay, which has been chosen as one of the most appropriate types of assay with normal human dermal fibroblasts (BJ cell line) and human immortalized keratinocytes (HaCaT cell line) [14]. Keratinocytes, which constitute almost $95 \%$ of the epidermis, are cells that create the first barrier that comes into contact with environmental factors, including synthetic materials, such as polyurethanes. An immortalized cell line was selected for the present study because the use of normal keratinocytes from skin biopsies as a model for in vitro studies on the biological effects of synthetic substances is limited due to donor variability, short culture lifetime, and variations between passages. Therefore, application of HaCaT keratinocytes has been a matter of choice with their lower variability, longterm growth in cultures, and lack of spontaneous tumorigenic properties [25]. The next skin barrier is the dermis, with fibroblasts as the main structural element. Therefore, using these two cell lines seems to be proper to this kind of test [26].

The results of the cytotoxicity direct contact assay showed that the response of normal human skin fibroblasts (BJ) and immortalized human keratinocytes $(\mathrm{HaCaT})$ to the studied PUs after $24 \mathrm{~h}$ of incubation was rather similar except PU-2, where HaCaTs were significantly more sensitive than BJ cells (Figs. 13, 14 , and 15). In the case of the BJ cell line, reactive zone size was similar after contact with PU-1 and PU-2 (moderate reactivity according to the U.S. Pharmacopeial Convention) [18] (Table 7), and in PU-4, a significantly stronger response of normal fibroblasts was noticed, but also on a moderate level. Keratinocytes showed moderate toxicity after incubation with PU-1 and PU-4 and severe after PU-2 treatment. The PU-3 film was the most biocompatible among all the tested samples with rather moderate reactivity against both cell lines (Fig. 15).

The obtained results were confirmed by assay measuring the absorbance of crystal violet released from cells (Fig. 15). Incubation of cells from both lines with the most biocompatible PU-3 sample showed no significant differences in cell viability compared to the control $(77 \%$ and $82 \%$ viability against the control, respectively). The remaining samples caused a statistically significant reduction in the viability of the tested cells in the range of $61-37 \%$, with the strongest response of $\mathrm{HaCaT}$ cells for the PU-2 sample. The cells located in the reactivity zone had strongly altered morphology: were shrunken and elongated with reduced adhesion.

The reason for the lowest toxicity of the PU-3 sample, compared to others, was probably its chemical and physicomechanical properties. PU-3 had the highest average molar mass, the lowest dispersity, and the highest crystallinity and heat of melting soft segments. Therefore, the content of small toxic molecule impurities was lower in PU-3 than in other samples. Moreover, the amount of small toxic molecules formed during the degradation of polymers responsible for toxicity was also lower in PU-3 since resistance of PU-3 films to hydrolysis after 6 weeks of incubation in Baxter fluid was the highest [27].
Table 7 Reactivity grades for direct contact test according to the U.S. Pharmacopeial Convention [23]

\begin{tabular}{cll}
\hline Grade & Reactivity & Description of reactivity zone \\
\hline 0 & None & No detectable zone around or under the specimen \\
1 & Slight & Some malformed or degenerated cells under the specimen \\
2 & Mild & Zone limited to area under specimen and less than $0.45 \mathrm{~cm}$ beyond the specimen \\
3 & Moderate & Zone extends $0.45-1.0 \mathrm{~cm}$ beyond the specimen \\
4 & Severe & Zone extends greater than $1.0 \mathrm{~cm}$ beyond the specimen \\
\hline
\end{tabular}


PU-3 containing PCL and IPDI had lower cytotoxicity compared to other polyurethanes with PA (PU-2, PU-4). It suggests that PA is a factor that slightly increased their toxicity. Lee et al. indicated that PCL was highly biocompatible and did not disturb the proliferation of MG63 osteosarcoma cells after 1 , 4 , or even 7 days of incubation (WST-1 assay) but polyurethanes containing PCL, HDI, and polyethylene glycol (PGE) disrupted this process [12]. Also, Lim et al. described only slightly lowering osteoblastic cell number on polyurethane films containing of HDI, PCL, and isomannide after 5 days of incubation (cell proliferation assay) [28].

IPDI derivatives might possess a high potential for use in biomedical applications. Valdés et al. studied the biological properties of PUs containing IPDI or 4,4'-methylenebis(cyclohexyl isocyanate) (HMDI), poly(propylene glycol) (PPG), and Disosorbide with direct contact assay according to the ISO 10993-5:2009 recommendation guidelines. Results indicated that the presence of HMDI but not IPDI caused significant lowering of HaCaT cells' viability after $72 \mathrm{~h}$ of incubation with appropriate polyurethane sample [29]. Also, Hsu et al. indicated on human skin fibroblast cells that PUs with IPDI, PCL, 2,2bis(hydroxymethyl) propionic acid (DMPA), and ethylenediamine (EDA) possess high biocompatibility [24]. This suggests that IPDI and PCL are suitable and optimal components of biocompatible PU-3 polyurethane film (rather mild reactivity), while stronger, moderate reactivity of PU-1, PU-2, and PU-4 might be a result of PA and ethylene glycol presence (additive action). No significant risk of the ethylene glycols is expected under normal use patterns. However, EG compounds share acute toxicity modes of action in vitro and in vivo, different in various species of animals and in humans [18].

The obtained results proved that PU-3 is rather a biocompatible polyurethane with mild reactivity, without significant lowering of cell viability and can be considered as a material for medical applications. However, replacement of $\mathrm{H}_{12} \mathrm{MDI}$ by HDI or IPDI, and butanediol-1.4 by EG, as potentially less toxic components did not reduce the toxicity of the studied polyurethanes. In our previous study conducted under identical conditions, we have revealed that polyurethane containing $\mathrm{H}_{12} \mathrm{MDI}$, PCL, and $\mathrm{BD}$ was significantly more biocompatible (slight/mild reactivity with reactivity zone equal 1.5 and $2.8 \mathrm{~mm}$ for $\mathrm{HaCaT}$ and $\mathrm{BJ}$ cells, respectively). Replacement of PCL with a mixture of PCL and PTMO (1:1) slightly increased the toxicity of the obtained material against $\mathrm{HaCaTs}$, with the reactivity zone equal $2 \mathrm{~mm}$ for both cell lines. Moreover, the replacement of PCL with PTMO dramatically increased the toxicity (reactivity zone equal 4 and $5 \mathrm{~mm}$ for HaCaT and BJ cells, respectively) [14].

\section{Conclusion}

The obtained results show that the modification of the polyurethane structure by replacing $\mathrm{H}_{12} \mathrm{MDI}$ by $\mathrm{HDI}$ or IPDI isocyanates, as well as the use of PCL and PA polyesters, allows changing the physicochemical interactions determining the phase structure and surface properties of the prepared polymer films. Analyses confirmed the expected structure of the obtained films as high molecular polyurethane elastomers. The studied materials show good hydrolytic stability during 6 weeks of incubation in a simulated body fluid and resistance for bacterial activity. IPDI and PCL are suitable and optimal components of the biocompatible PU-3 polyurethane film (rather mild reactivity), while the stronger, moderate reactivity of PU-1, PU-2, and PU-4 may be due to the presence of PA. The main conclusion of this work is that no significant risk should be expected when using ethylene glycol as an effective extender of polyurethane chains.

The best potential candidate for use as a biomaterial (among the studied samples) is PU-3 polyurethane film based on isophorone diisocyanate and poly( $\varepsilon$-caprolactone) diol. It has the highest crystallinity, large molecular weight, lowest degree of polydispersity, and significant hydrophobicity as well as the highest biocompatibility. Therefore, PU-3 can be considered as a material with potential application in biomedicine due to its rather mild toxicity against human normal fibroblasts and immortalized keratinocytes. However, it is necessary to modify the conditions for forming the film to obtain the required mechanical properties and long-term in vitro and in vivo studies are needed.

Funding information This scientific work has been supported by the Rzeszow University of Technology under contract no. U-DS.CS.18.001. The biological part of this study (cell culture assay) was supported by grant 2014/13/D/NZ3/02825 from the National Science Centre, Poland.

\section{Compliance with ethical standards}

Conflict of interest The authors declare that they have no conflicts of interest.

Open Access This article is licensed under a Creative Commons Attribution 4.0 International License, which permits use, sharing, adaptation, distribution and reproduction in any medium or format, as long as you give appropriate credit to the original author(s) and the source, provide a link to the Creative Commons licence, and indicate if changes were made. The images or other third party material in this article are included in the article's Creative Commons licence, unless indicated otherwise in a credit line to the material. If material is not included in the article's Creative Commons licence and your intended use is not permitted by statutory regulation or exceeds the permitted use, you will need to obtain permission directly from the copyright holder. To view a copy of this licence, visit http://creativecommons.org/licenses/by/4.0/.

\section{References}

1. Wang W, Wang C (2012) 3 - Polyurethane for biomedical applications: a review of recent developments. In: The design and manufacture of medical devices, J.P. Davim, Editor. Woodhead Publishing. pp. 115-151. https://doi.org/10.1016/B978-1-90756872-5.50003-0 
2. Bharadwaz A, Jayasuriya AC (2020) Recent trends in the application of widely used natural and synthetic polymer nanocomposites in bone tissue regeneration. Mater Sci Eng C 110:110698. https:// doi.org/10.1016/j.msec.2020.110698

3. Aidun A, Zamanian A, Ghorbani F (2020) Immobilization of polywinyl alcohol-siloxane on the oxygen plasma-modified polyurethane-carbon nanotube composite matrix. J Appl Polym Sci 137:48477. https://doi.org/10.1002/app.48477

4. Burke A, Hasirci N (2004) Polyurethanes in biomedical applications. Biomaterials pp 83-101 Biomaterials. Advances in experimental medicine and biology, vol 553. Springer, Boston, MA https://doi.org/10.1007/978-0-306-48584-8_7

5. Gorna K, Gogolewski S (2003) Preparation, degradation, and calcification of biodegradable polyurethane foams for bone graft substitutes. Journal of Biomed Mater Res Part A 67A:813-827. https:// doi.org/10.1002/jbm.a. 10148

6. Kavlock KD, Pechar TW, Hollinger JO, Guelcher SA, Goldstein AS (2007) Synthesis and characterization of segmented poly(esterurethane urea) elastomers for bone tissue engineering. Acta Biomaterialia 3: 475-484. https://doi.org/10.1016/j.actbio. 2007.02.001

7. Santerre JP, Woodhouse K, Laroche G, Labow RS (2005) Understanding the biodegradation of polyurethanes: from classical implants to tissue engineering materials. Biomaterials 26:7457. https://doi.org/10.1016/j.biomaterials.2005.05.079

8. Wang C, Xie J, Xiao X, (2019) Development of nontoxic biodegradable polyurethanes based on polyhydroxyalkanoate and 1lysine diisocyanate with improved mechanical properties as new elastomers scaffolds. Polymers 11, 1927. https://doi.org/10.3390/ polym 11121927

9. Hao H, Shao J et al (2016) Synthesis and characterization of biodegradable lysine-based waterborne polyurethane for soft tissue engineering applications. Biomaterials Sci 4:1682-1690. https:// doi.org/10.1039/c6bm00588h

10. Norren A, Zia KM et al (2020) Structural elucidation and biological amplitude of modified hydroxyethylcellulosepolydimethylsiloxane based polyurethane. Inter J Biolog Macromol 150:426-440. https://doi.org/10.1016/j.ijbiomac.2020. 01.288

11. Park JC, Park BJ, Lee DH, Sun H, Kim D-G, Kwon O-H (2002) Evaluation of the cytotoxicity of polyetherurethane (PU) film containing zinc diethyldithiocarbamate (ZDEC) on various cell lines. Yonsei Med J 43:518. https://doi.org/10.1016/j.msec.2018.07.082

12. Le SY et al, Synthesis and characterization of polycaprolactonebased polyurethanes for the fabrication of elastic guided bone regeneration membrane. Bio Med Res Inter Vol 2018, Article ID 3240571. https://doi.org/10.1155/2018/3240571

13. Zhu $\mathrm{R}$ et al (2017) Influence of hard segments on the thermal, phase-separated morphology, mechanical, and biological properties of polycarbonate urethanes. J Appl Sci 7:306. https://doi.org/10. 3390/app7030306

14. Król P, Uram Ł, Król B, Pielichowska K, Walczak M (2018) Study of chemical, physico-mechanical and biological properties of 4,4'methylenebis (cyclohexyl isocyanate)-based polyurethane films. Mater Sci Eng C 93:483-494. https://doi.org/10.1016/j.msec. 2018.07.082

15. Kim HW, Knowles JC, Kim HE (2004) Hydroxyapatite/poly(عcaprolactone) composite coatings on hydroxyapatite porous bone scaffold for drug delivery. Biomaterials 25:1279-1287. https://doi. org/10.1016/j.biomaterials.2003.08.045
16. Serrano MC, Pagani, Vallet-Regi M, Pena J, Ramila A, Izquierdo I, Portoles MT (2004) In vitro biocompatibility assessment of poly $(\varepsilon-$ caprolactone) films using L929 mouse fibroblasts. Biomaterials 25: 5603-5611. https://doi.org/10.1016/j.biomaterials.2004.01.037

17. Williams JM, Schek RM, Flanagan CL, Krebsbach PH, Feinberg SE, Hollister SJ, Das S (2005) Bone tissue engineering using polycaprolactone scaffolds fabricated via selective laser sintering. Biomaterials 23:4817-4827. https://doi.org/10.1016/j.biomaterials. 2004.11.057

18. Fowles J, Banton M, Klapacz J, Shen H (2017) A toxicological review of the ethylene glycol series: commonalities and differences in toxicity and modes of action. Toxicology Letters 278:66-83. https://doi.org/10.1016/j.toxlet.2017.06.009

19. Seymour RW, Estes GM, Cooper SL (1970) Infrared studies of segmented polyurethane elastomers. I. Hydrogen bonding. Macromolecules 3:579-583. https://doi.org/10.1021/ma60017a021

20. Żenkiewicz M (2006) The analysis of principal conditions of van Oss-Chaunhury-Good's method in investigations of surface layers of polymeric materials. Polimery (Polish) 51:169-176. https://doi. org/10.14314/polimery.2006.169

21. Zisman WA (1964) Relation of the equilibrium contact angle to liquid and solid constitution. Advances in Chemistry 43:1. https:// doi.org/10.1021/ba-1964-0043.ch001

22. Negoro S, Shinagawa H, Nakata A, Kinoshita, Hotozaki T, Okada H (1980) Plasmid control of 6-aminohexanoic acid cyclic dimer degradation enzymes of Flavobacterium sp. KI72. J Bacteriol 43: 328-245. http://b.asm.org/on july 2019

23. U.S. Pharmacopeial Convention, Biological reactivity tests, in vitro in interim revision announcement official, 1. http://www.usp.org/ sites/default/files/usp_pdf/EN/USPNF/iras/gc-87-biologicalreactivity.pdf, (2015), Accessed date: 18 September 2017

24. Hsu SH et al (2018) Evaluation and characterization of waterborne biodegradable polyurethane films for prevention of tendon postoperative adhesion. Intern. J Nanomedicine 13:5485-5497. https:// doi.org/10.2147/IJN.S169825

25. Szuster M, Uram Ł, Filipowicz-Rachwał A, Wołowiec S, WałajtysRode E Evaluation of the localization and biological effects of PAMAM G3 dendrimer-biotin/pyridoxal conjugate as $\mathrm{HaCaT}$ keratinocyte targeted nanocarrier. Acta Biochim Pol 66:191-200. https://doi.org/10.18388/abp.2018_2767

26. Yari A, Yeganeh H, Bakhshi H (2012) Synthesis and evaluation of novel absorptive and antibacterial polyurethane membranes as wound dressing. J Mater Sci Mater Med 23:2187-2202. https:// doi.org/10.1007/s10856-012-4683-6

27. Fairbanks BD, Gunatillake PA, Meagher L (2015) Biomedical applications of polymers derived by reversible addition - fragmentation chain-transfer (RAFT). Adv. Drug Deliv Rev 91:141-152. https://doi.org/10.1016/j.addr.2015.05.016

28. BSG V, CSB G, Gomes PT et al (2018) Synthesis and characterization of isosorbide-based polyurethanes exhibiting low cytotoxicity towards HaCaT human skin cells. Polymers (Basel) 10:1170. https://doi.org/10.3390/polym10101170

29. Lim DI, Park HS, Park JH, Knowles JC, Gong MS (2013) Application of high-strength biodegradable polyurethanes containing different ratios of biobased isomannide and poly $(\epsilon$ caprolactone) diol. J Bioact Compat Polym 28:274-288. https:// doi.org/10.1177/0883911513484572

Publisher's note Springer Nature remains neutral with regard to jurisdictional claims in published maps and institutional affiliations. 